\title{
Geochemistry of the Neoarchaean Volcanic Rocks of the Kilimafedha Greenstone Belt, Northeastern Tanzania
}

\author{
Charles W. Messo, Shukrani Manya, and Makenya A. H. Maboko \\ Department of Geology, University of Dar es Salaam, P.O. Box 35052, Dar es Salaam, Tanzania \\ Correspondence should be addressed to Shukrani Manya, shukrani73@udsm.ac.tz
}

Received 30 March 2012; Revised 6 July 2012; Accepted 22 July 2012

Academic Editor: Michael O. Garcia

Copyright ( $) 2012$ Charles W. Messo et al. This is an open access article distributed under the Creative Commons Attribution License, which permits unrestricted use, distribution, and reproduction in any medium, provided the original work is properly cited.

\begin{abstract}
The Neoarchaean volcanic rocks of the Kilimafedha greenstone belt consist of three petrological types that are closely associated in space and time: the predominant intermediate volcanic rocks with intermediate calc-alkaline to tholeiitic affinities, the volumetrically minor tholeiitic basalts, and rhyolites. The tholeiitic basalts are characterized by slightly depleted LREE to nearly flat REE patterns with no Eu anomalies but have negative anomalies of $\mathrm{Nb}$. The intermediate volcanic rocks exhibit very coherent, fractionated REE patterns, slightly negative to absent Eu anomalies, depletion in $\mathrm{Nb}$, $\mathrm{Ta}$, and $\mathrm{Ti}$ in multielement spidergrams, and enrichment of HFSE relative to MORB. Compared to the other two suites, the rhyolites are characterized by low concentrations of $\mathrm{TiO}_{2}$ and overall low abundances of total REE, as well as large negative Ti, Sr, and Eu anomalies. The three suites have a $\varepsilon \mathrm{Nd}(2.7 \mathrm{Ga})$ values in the range of -0.51 to +5.17 . The geochemical features of the tholeiitic basalts are interpreted in terms of derivation from higher degrees of partial melting of a peridotite mantle wedge that has been variably metasomatized by aqueous fluids derived from dehydration of the subducting slab. The rocks showing intermediate affinities are interpreted to have been formed as differentiates of a primary magma formed later by lower degrees of partial melting of a garnet free mantle wedge that was strongly metasomatized by both fluid and melt derived from the subducting oceanic slab. The rhyolites are best interpreted as having been formed by shallow level fractional crystallization of the intermediate volcanic rocks involving plagioclase and Tirich phases like ilmenite and magnetite as well as REE-rich phases like apatite, zircon, monazite, and allanite. The close spatial association of the three petrological types in the Kilimafedha greenstone belt is interpreted as reflecting their formation in an evolving late Archaean island arc.
\end{abstract}

\section{Introduction}

The Kilimafedha greenstone belt of northeast Tanzania is one of the six greenstone belts of the Tanzania Craton occurring in the northern part of the country in the area south and east of the Lake Victoria. Other greenstone belts include the Sukumaland, Shinyanga-Malita, Nzega, Musoma-Mara, and Iramba-Sekenke [1, Figure 1]. All of these greenstone belts are prospective for gold mineralization with several largescale mines now in operation including the Bulyanhulu, Tulawaka, Geita, Buzwagi, North Mara, and Golden Pride (Figure 1). Because of their economic significance, the greenstone belts of the Tanzania Craton have recently been the focus of research on the processes that control gold mineralization (e.g., $[2,3])$, lithostratigraphical relationships (e.g., $[4,5])$, geochemistry, and geochronology (e.g., [6-12]). These studies have helped us to better understand, among other things, the timing of and the processes responsible for the formation of the earliest continental crust in Tanzania as well as the ancient tectonic settings in which the greenstone belts formed.

Previous geological work in the Kilimafedha greenstone belt is limited to the geological mapping done by Macfarlane [14] and more recently to geochronological investigation by Wirth et al. [9] who reported zircon $\mathrm{Pb}-\mathrm{Pb}$ ages from rhyolites and granitic intrusions in the area. In this paper, we present whole-rock major and trace element as well as the Nd-isotopic compositions for the volcanic rocks of the Kilimafedha greenstone belt around the Ikoma area with the aim of unraveling their petrogenesis and tectonic 

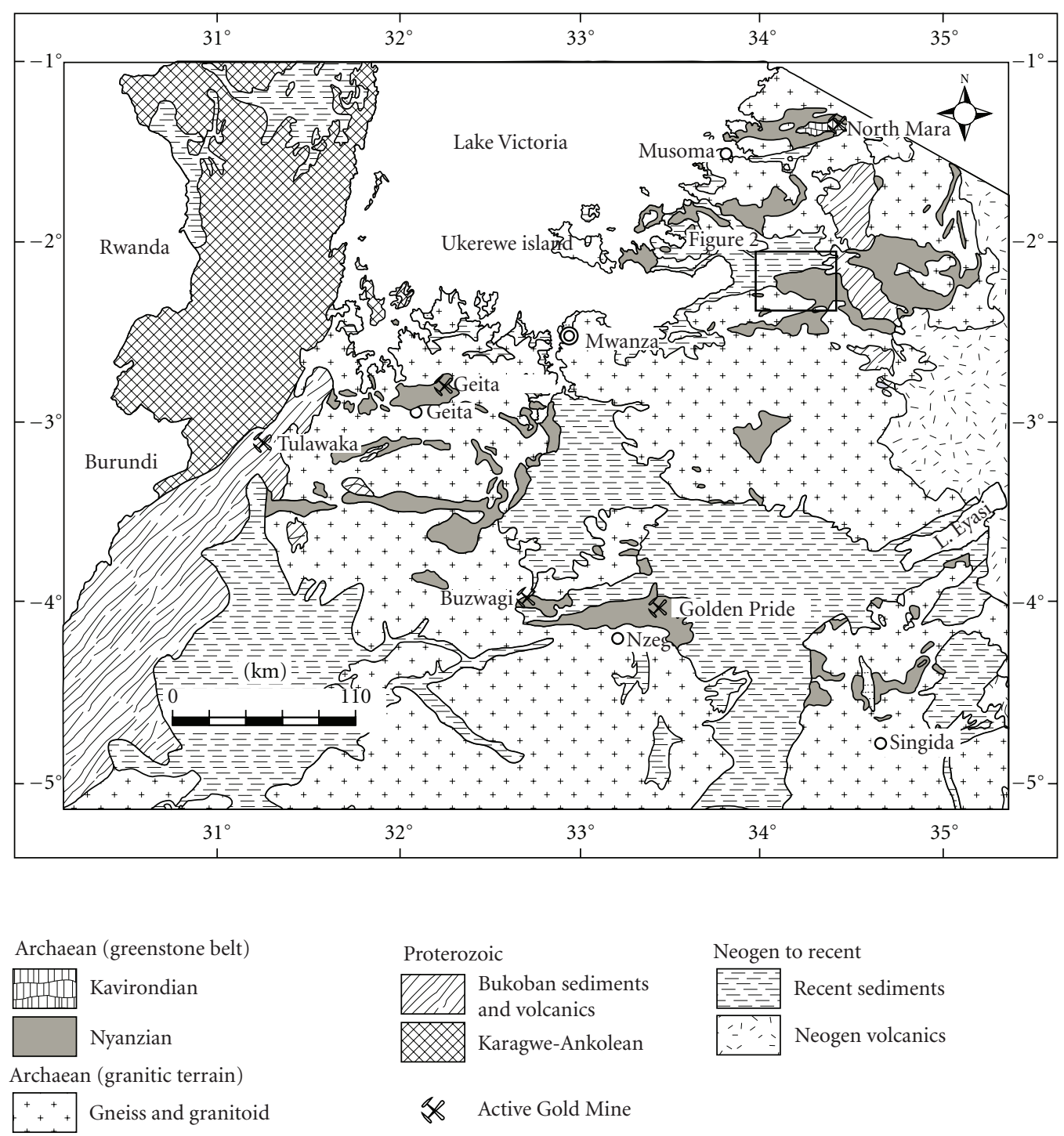

FIgURE 1: Geological map of the northern part of the Tanzania Craton showing the greenstone belts in the area around Lake Victoria (modified after [13]). The inset frame indicates the area of study in Figure 2.

setting of eruption. The results of this study complement the information available from other greenstone belts of the Tanzania Craton on the processes that led to the growth of the continental crust during the late Archaean.

\section{Geological Setting}

The Tanzania Craton forms the central nucleus of Tanzania and extends northwards into southwestern Kenya and southeastern Uganda. The Craton is divided into two main lithological units: the Dodoman belt which is comprised of high-grade metamorphic rocks, granite, granitic gneisses, and migmatites of central Tanzania and the low-grade granite-greenstone terrane of northern Tanzania, southwestern Kenya, and southwestern Uganda [15]. The lowgrade granite-greenstone terrane comprises mafic to felsic volcanic rocks and metasedimentary rocks including shales, sandstones, siltstones, chert, and banded iron formation (BIF) which are in turn intruded by granites.

Robust geochronological data shows that the oldest greenstones in the Tanzania Craton are the mafic volcanic rocks of the Rwamagana area in the Sukumaland greenstone belt (Figure 1). These yielded a Sm-Nd isochron age of 2823 $\pm 44 \mathrm{Ma}$ reported by Manya and Maboko [7]. The youngest volcanism in the greenstone belts of the Tanzania Craton is from the Musoma-Mara greenstone belt reported by Manya et al. [10] as indicated by a zircon U-Pb age of $2667 \pm$ $8 \mathrm{Ma}$ obtained from dacites collected near Tarime (Figure 1). A more thorough review of the geochronology of the greenstones and intruding granites of the Tanzania Craton can be found in Borg and Krogh [6] and Manya et al. [10].

The Kilimafedha greenstone belt forms an asymmetrical horseshoe-shaped exposure of metavolcanic and minor 
metasedimentary rocks in the area east and southeast of Lake Victoria (Figure 2). Most of the greenstone exposures including the old Kilimafedha mining district lie within the Serengeti National park. The samples collected for this study, however, were sampled outside the National park boundary in the Ikoma area (Figure 2). According to Macfarlane [14], the greenstone sequences start with a poorly preserved mafic volcanic unit now converted into actinolite and hornblende schist (Figure 3 ) in the extreme southeastern and northern margins of the belt (within the Serengeti National Park boundary), and the rocks are thus metamorphosed into greenschist facies except for the hornblende schists that are proximal to granitic intrusions. This unit has locally been found to be pillowed suggesting extrusion of the lavas under water.

The mafic volcanic rocks are overlain by a more extensive and better preserved thick sequence of intermediate volcanic rocks with infrequent felsic volcanic rocks patched in the intermediate rocks (Figure 3 ). This sequence locally contains thin horizons of tuff and metasediments including chert, jaspilite, and quartzite. The felsic volcanic rocks were dated by Wirth et al. [9] who reported ${ }^{207} \mathrm{~Pb} /{ }^{206} \mathrm{~Pb}$ zircon ages of $2712 \pm 5 \mathrm{Ma}(\mathrm{MSWD}=0.35)$ and $2720 \pm 5 \mathrm{Ma}(\mathrm{MSWD}=$ $1.9)$.

More fresh exposures of the greenstone sequence occur in the area near Fort Ikoma (Figure 2) close to the northern boundary of the greenstone belt. In this area, the most common rock types include amygdaloidal andesite with streams of vesicles filled up with quartz, epidote, and chlorite (Figure 4). Other less vesicular types have large phenocrysts of albite-oligoclase. Sediments intercalated with metavolcanics are largely metamorphosed ferruginous quartzite, siltstones, mudstones, and felsic tuffs.

The whole sequence has been deformed resulting into the development of a steeply dipping $\mathrm{N}$ to $\mathrm{NW}$ trending foliation. Folding is indicated by isoclinal contortions in the ferruginous quartzite [14]. Late orogenic granites outcrop along the eastern, northern, and southwestern margins of the greenstone belt. The granite-greenstone contact along the northern margin has been decorated with minor metagabbroic intrusions that have been correlated with the larger Nyamongo gabbros of the Musoma-Mara greenstone belt [16]. Neoproterozoic arenaceous to argillaceous sedimentary rocks of the Ikorongo Group [17] unconformably overlie all the Archaean rocks in the area.

\section{Sampling and Analytical Methodology}

Samples were obtained from surface outcrops, and sampling was dictated by the degree of accessibility, exposure, and freshness of the outcrops. Fifty volcanic rocks samples were collected in the field and were subsequently prepared for laboratory chemical analyses. All 50 samples were analyzed for major element compositions, but only 18 representative samples from distinguished suites were analyzed for trace element compositions (see Figure 2 for sample locations). For chemical analyses, the samples were pulverized in an agate mill at the Southern and Eastern Africa Mineral Centre (SEAMIC) Laboratories, Dar es Salaam. Samples were first dried in an oven at $110^{\circ} \mathrm{C}$, and $1 \mathrm{~g}$ of the powdered sample was mixed with $7 \mathrm{~g}$ of lithium metaborate and fused in a furnace at $1000^{\circ} \mathrm{C}$ for about 10 minutes to make glass beads. The glass beads were analyzed using an SRS 3000 Siemens X-ray Fluorescence Spectrometer at the same laboratories following procedures reported in Messo [18]. Loss on ignition (LOI) was determined by repeatedly heating the samples in a furnace at $1010^{\circ} \mathrm{C}$ and cooling until constant weight was achieved.

The samples were also analyzed for trace elements at the Activation Laboratories of Ancaster, Ontario, Canada. $0.25 \mathrm{~g}$ of each sample was mixed with a flux of lithium metaborate and lithium tetraborate and fused in an induction furnace. The melt was immediately poured into a solution of $5 \%$ $\mathrm{HNO}_{3}$ containing an internal In standard and thoroughly mixed for $\sim 30$ minutes to achieve complete dissolution. An aliquot of the sample solution was spiked with internal In and $\mathrm{Rh}$ standards to cover the entire mass range and diluted 6000 times prior to introduction into a Perkin Elmer SCIEX ELAN 6000 ICP-MS for trace elements analysis. Precision and accuracy as deduced from replicate analyses of the BIR-1 and W2 standards are $5-10 \%$. The analytical reproducibility deduced from replicate analyses of the samples is better than $8 \%$ for most trace elements.

Nine samples were also analysed for $\mathrm{Sm}-\mathrm{Nd}$ isotopic compositions as well as $\mathrm{Sm}$ and $\mathrm{Nd}$ concentrations using a Triton-MC Thermal Ionization Mass Spectrometer at the Activation Laboratories of Ontario, Canada. Aliquots of the powdered rock samples were spiked with a ${ }^{149} \mathrm{Sm}^{146} \mathrm{Nd}$ mixed solution prior to decomposition using a mixture of $\mathrm{HF}, \mathrm{HNO}_{3}$, and $\mathrm{HClO}_{4}$. The REEs were separated using conventional cation-exchange techniques. Sm and $\mathrm{Nd}$ were separated by extraction chromatography on HDEHP covered teflon powder. Total blanks are 0.1-0.2 ng for Sm and 0.1$0.5 \mathrm{ng}$ for $\mathrm{Nd}$ and are negligible. The accuracy of the Sm and $\mathrm{Nd}$ analyses is $\pm 0.5 \%$ corresponding to errors in the ${ }^{147} \mathrm{Sm} /{ }^{144} \mathrm{Nd}$ ratios of $\pm 0.5 \%(2 \sigma)$. The ${ }^{143} \mathrm{Nd} /{ }^{144} \mathrm{Nd}$ ratios are calculated relative to the value of 0.511860 for the $\mathrm{La}$ Jolla standard. During the period of analysis, the weighted average of $10 \mathrm{La}$ Jolla Nd-standard runs yielded $0.511872 \pm$ $15(2 \sigma)$ for ${ }^{143} \mathrm{Nd} /{ }^{144} \mathrm{Nd}$, using a ${ }^{146} \mathrm{Nd} /{ }^{144} \mathrm{Nd}$ value of 0.7219 for normalization.

\section{Geochemistry}

4.1. Alteration and Element Mobility. Alteration of metavolcanic rocks is a common phenomenon, in particular for Archaean greenstones, and is typically characterized by high loss on ignition (LOI) values and increased scatter of major and large ion lithophile elements. In this regard, the volcanic rocks, collected for this study, are variably affected by greenschist metamorphism, so it is expected that major and LILE are also affected by alteration. However, numerous studies have demonstrated that rare earth elements (REEs) and high field strength elements (HFSEs) remain relatively undisturbed at greenschist facies and even higher grades of metamorphism $[19,20]$. So in this study major and LILE are used with great care, and emphasize is placed on the REE and HFSE. 

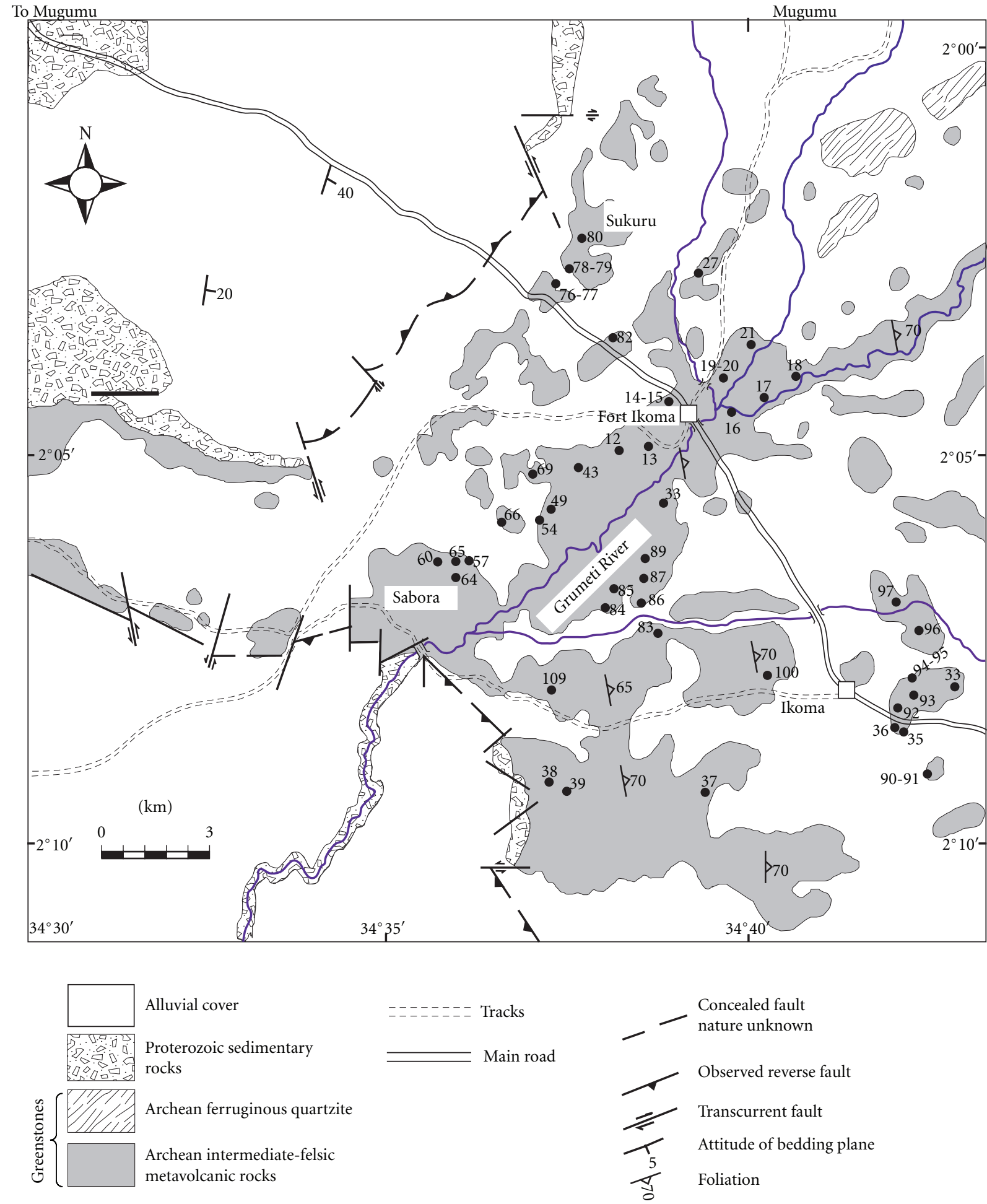

FIGURE 2: Geological map of the Kilimafedha greenstone belt showing sample locations (modified after [14]).

4.2. Classification and Petrography. The volcanic rocks of the Kilimafedha greenstone belt represent a mafic, intermediate to felsic compositional continuum as indicated by their wide range of $\mathrm{SiO}_{2}$ contents $(48.48-76.02 \mathrm{wt} \%)$. Out of a total of 50 samples that were analyzed for major elements and as shown in Figure 4 and 7 samples are basaltic in composition $\left(\mathrm{SiO}_{2}=48.48-51.57 \mathrm{wt} \%\right), 40$ samples show intermediate compositions ranging from basaltic andesites to basaltic trachyandesites, which are predominant; andesites to dacites $\left(\mathrm{SiO}_{2}=52.51-66.80 \mathrm{wt} \%\right)$; only 3 samples are rhyolites $\left(\mathrm{SiO}_{2}=75.52-76.02 \mathrm{wt} \%\right.$, values quoted on water free basis), revealing the sporadic nature of the more felsic 


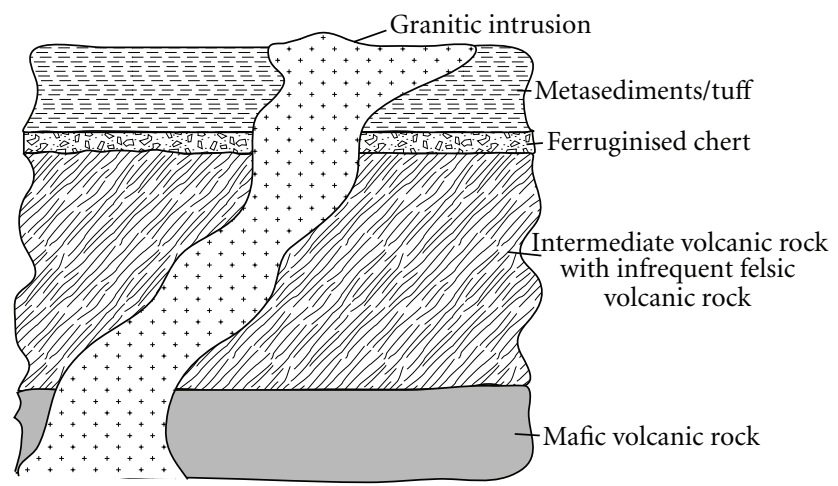

FIGURE 3: Diagrammatic representation of the stratigraphic sequence of Kilimafedha greenstone belt, not to scale (modified after [14]).

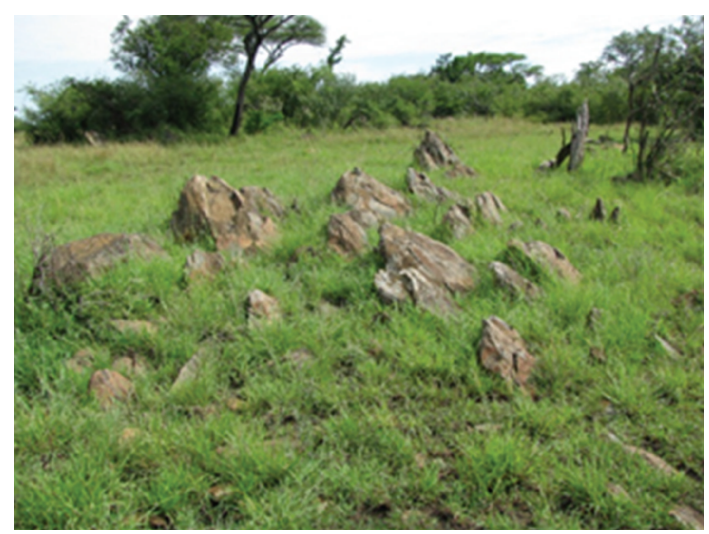

(a)

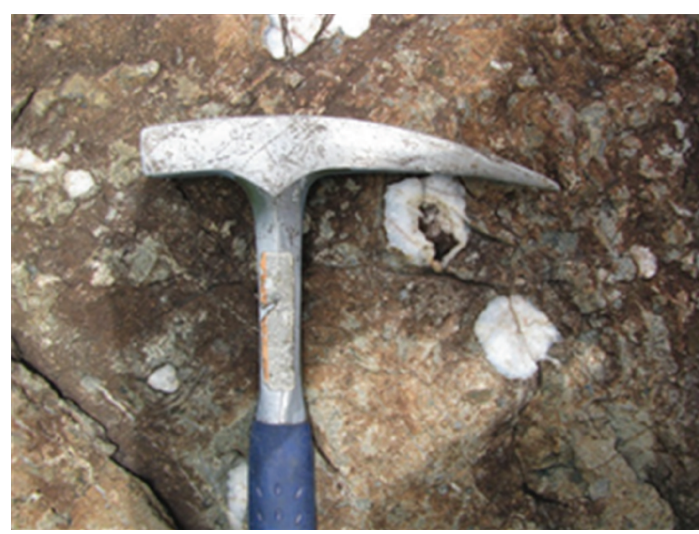

(b)

FIGURE 4: Outcrop photographs showing Ikoma foliated metabasalts with an appearance of a schist (a) and amygdaloidal andesite with vesicles filled in with secondary quartz (b).

rocks. The predominance of the basaltic trachyandesitic rocks and the nature of these rocks are unique to the Kilimafedha greenstone belt (Figure 5).

Using the Winchester and Floyd [22] classification scheme which is suitable for classifying metamorphosed rocks, of the 18 samples that were analyzed for both major and trace elements, four samples plot along the boundary between subalkaline basalt and andesite/basalt, eleven others plot in the fields of andesite/basalt and andesites, and three samples plot as rhyolites (Figure 6). The basalts to andesitic basalts exhibit tholeiitic affinity, the intermediate rocks intermediate geochemical characteristics between tholeiitic and calc-alkaline affinities, whereas the rhyolites are calcalkaline. Accordingly, the rocks are henceforth subdivided into three suites: the tholeiitic basalts, the intermediate volcanic rocks, and the rhyolites.

The primary petrographic features of the tholeiitic basalts are strongly obliterated by alteration which has resulted in the formation of chlorite, epidote, and hornblendic amphibole which appear to form after olivines and pyroxenes. The predominant intermediate rocks are often amygdaloidal, with streams of vesicles filled up with quartz, epidote, and chlorite. Other less vesicular types have large phenocrysts of albite-oligoclase. Most felsic rocks have fine matrix of quartz and sericitized feldspars with sparse phenocrysts of quartz and altered feldspars. The presence of chlorite and epidote in the Kilimafedha volcanic rocks suggests that these rocks have mainly been metamorphosed into greenschist facies.

\subsection{Major and Trace Element Geochemistry}

4.3.1. Tholeiitic Basalts. Major and trace element composition of the tholeiitic basalts of the Kilimafedha greenstone belt are presented in Table 1 . The rocks have $\mathrm{SiO}_{2}$ compositions that are in the range of 48.48-51.57 wt $\%, \mathrm{TiO}_{2}=0.61-$ $1.80 \mathrm{wt} \%, \mathrm{Fe}_{2} \mathrm{O}_{3}=6.32-13.92 \mathrm{wt} \%, \mathrm{MgO}=5.56-8.49 \mathrm{wt} \%$, and $\mathrm{Mg}$ numbers, calculated as $100 \times \mathrm{Mg}^{2+} /\left(\mathrm{Mg}^{2+}+\mathrm{Fe}_{\text {total }}{ }^{2+}\right)$, range from 47 to 73 (the major elements presented on a water free basis). $\mathrm{Cr}$ and $\mathrm{Ni}$ contents are $160-240 \mathrm{ppm}$ and 90-190 ppm, respectively. La contents vary considerably (1.7-9.2 ppm), whereas $\mathrm{Yb}$ contents range from 1.7 to $3.1 \mathrm{ppm}$ resulting in $\mathrm{La} / \mathrm{Yb}$ ratios of 1.00-4.00 (Table 1). On major and trace element bivariate plots (Figure 7), $\mathrm{Fe}_{2} \mathrm{O}_{3}$, $\mathrm{MgO}, \mathrm{CaO}$, and $\mathrm{Ni}$ correlate negatively with $\mathrm{SiO}_{2}$ pointing to fractionation signature or cogenetic relationship. The tholeiitic basalts alone do not show any major trends most 


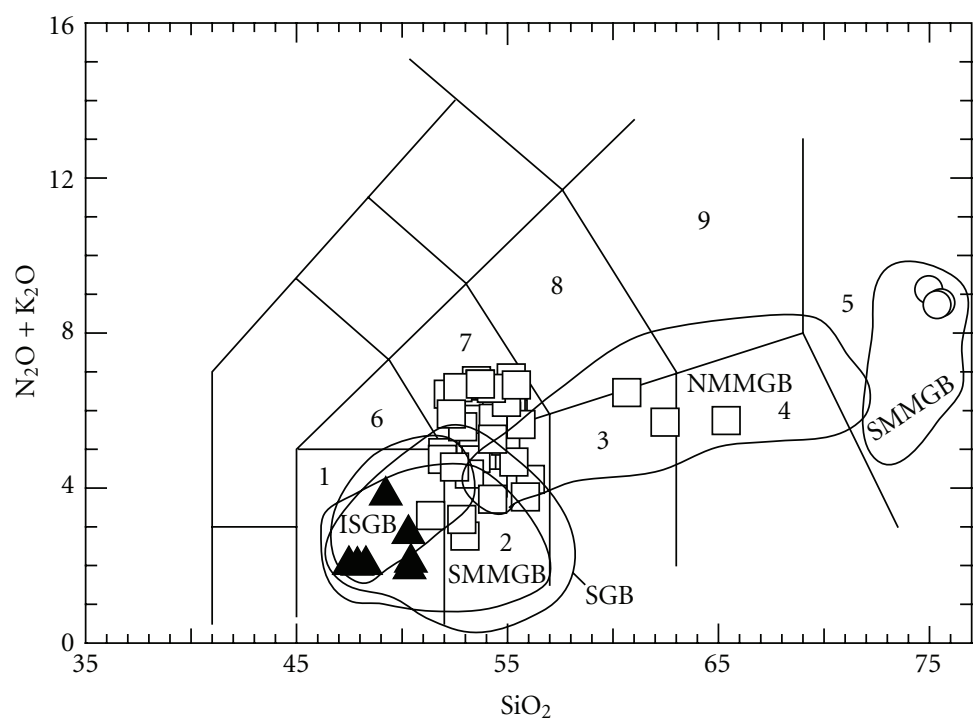

FIgURE 5: TAS classification diagram of Le Maitre et al. [21] for the Kilimafedha volcanic rocks. Also shown in the diagram are fields for volcanic rocks from other greenstone belts of the Tanzania Craton: ISGB: Iramba-Sekenke greenstone belt, SGB: Sukumaland greenstone belt, SMMGB: Southern Musoma-Mara greenstone belt, and NMMGB: Northern Musoma-Mara greenstone belt. Numbers in the diagram indicate fields as follows: 1: basalt, 2: basaltic andesite, 3: andesite, 4: dacite, 5: rhyolite, 6: trachybasalt, 7: basaltic trachyandesite, 8: trachyandesite, and 9: trachydacite.

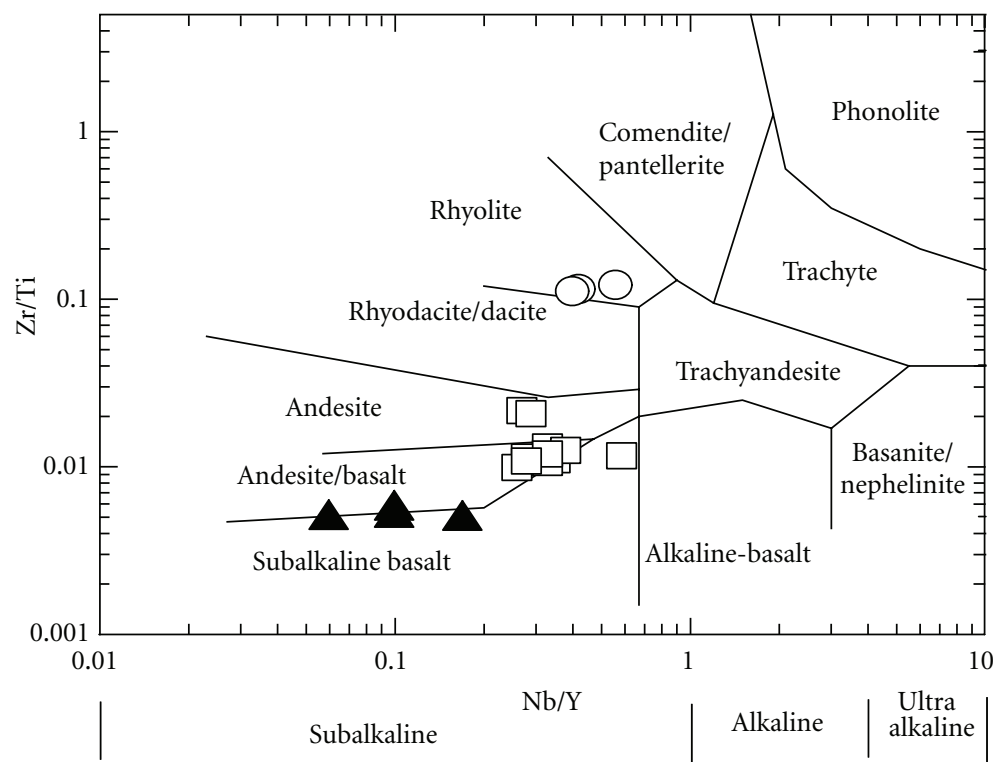

Figure 6: Classification of the Kilimafedha volcanic rocks using the Nb/Y-Zr/Ti diagram of Winchester and Floyd [22]. Symbols are filled triangles: tholeiitic basalts, open squares: intermediate volcanic rocks, and open cycles: rhyolites.

likely due to the small number of samples and their restricted range in $\mathrm{SiO}_{2}$ content.

The rocks display slightly depleted LREE to nearly flat REE patterns (Figure $8(\mathrm{a})$ ) that are characterized by $\mathrm{La} / \mathrm{Sm}_{\mathrm{CN}}$ and $\mathrm{La} / \mathrm{Yb}_{\mathrm{CN}}$ ratios of $0.8-0.9$ and $0.72-1.06$, respectively, except for sample MU 69 which is relatively enriched in LREE $\left(\mathrm{La} / \mathrm{Sm}_{\mathrm{CN}}=1.7\right.$ and $\left.\mathrm{La} / \mathrm{Yb}_{\mathrm{CN}}=2.89\right)$ compared to the other three samples (where $\mathrm{CN}$ refers to chondrite normalized values). The $\mathrm{La} / \mathrm{Sm}_{\mathrm{CN}}$ and $\mathrm{La} / \mathrm{Yb}_{\mathrm{CN}}$ values of the three samples (MU 69 excluded) are slightly higher than those of NMORB
$\left(\mathrm{La} / \mathrm{Sm}_{\mathrm{CN}}=0.6, \mathrm{La} / \mathrm{Yb}_{\mathrm{CN}}=0.59 ;[23]\right)$ indicating relative enrichment of the LREE in the Kilimafedha tholeiites. The samples do not show any Eu anomalies $\left(\mathrm{Eu} / \mathrm{Eu}^{*}=0.90-\right.$ 1.10). The samples were also plotted on primitive mantle spidergrams (Figure 9(a)), where they display enrichment in $\mathrm{Rb}, \mathrm{Ba}, \mathrm{Th}, \mathrm{K}$, and $\mathrm{Pb}$ relative to the more compatible elements with flatter multielement patterns characterized by negative $\mathrm{Nb}$ anomalies $\left(\mathrm{Nb} / \mathrm{La}_{\mathrm{pm}}=0.42-0.64\right)$ and minor negative $\mathrm{Ti}$ anomalies (where pm refers to primitive mantle normalized values). 


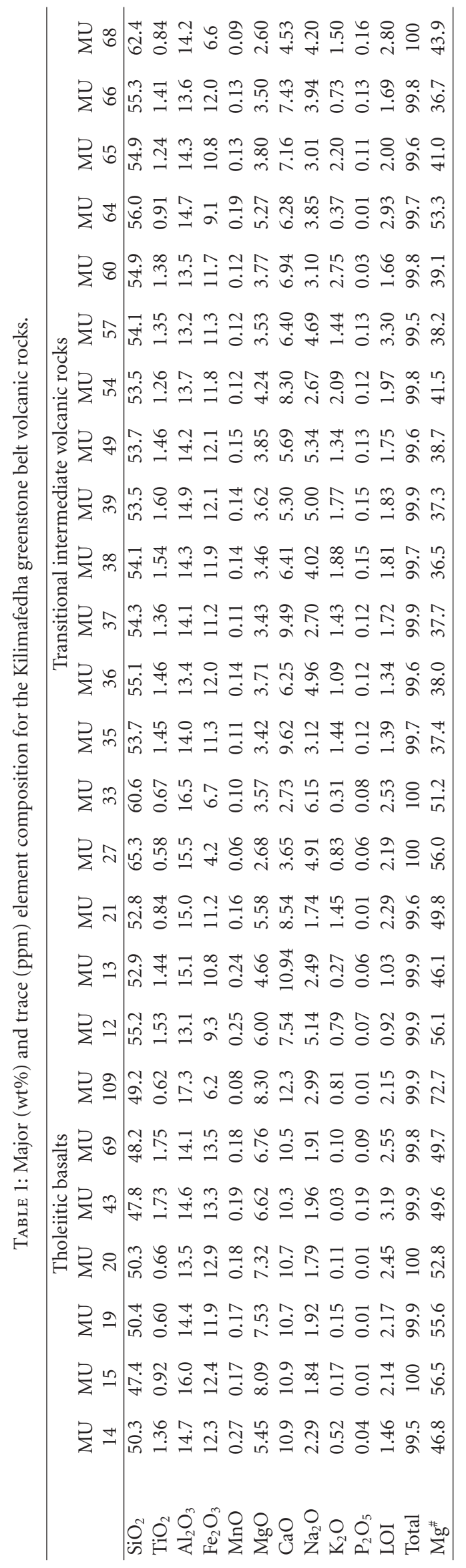




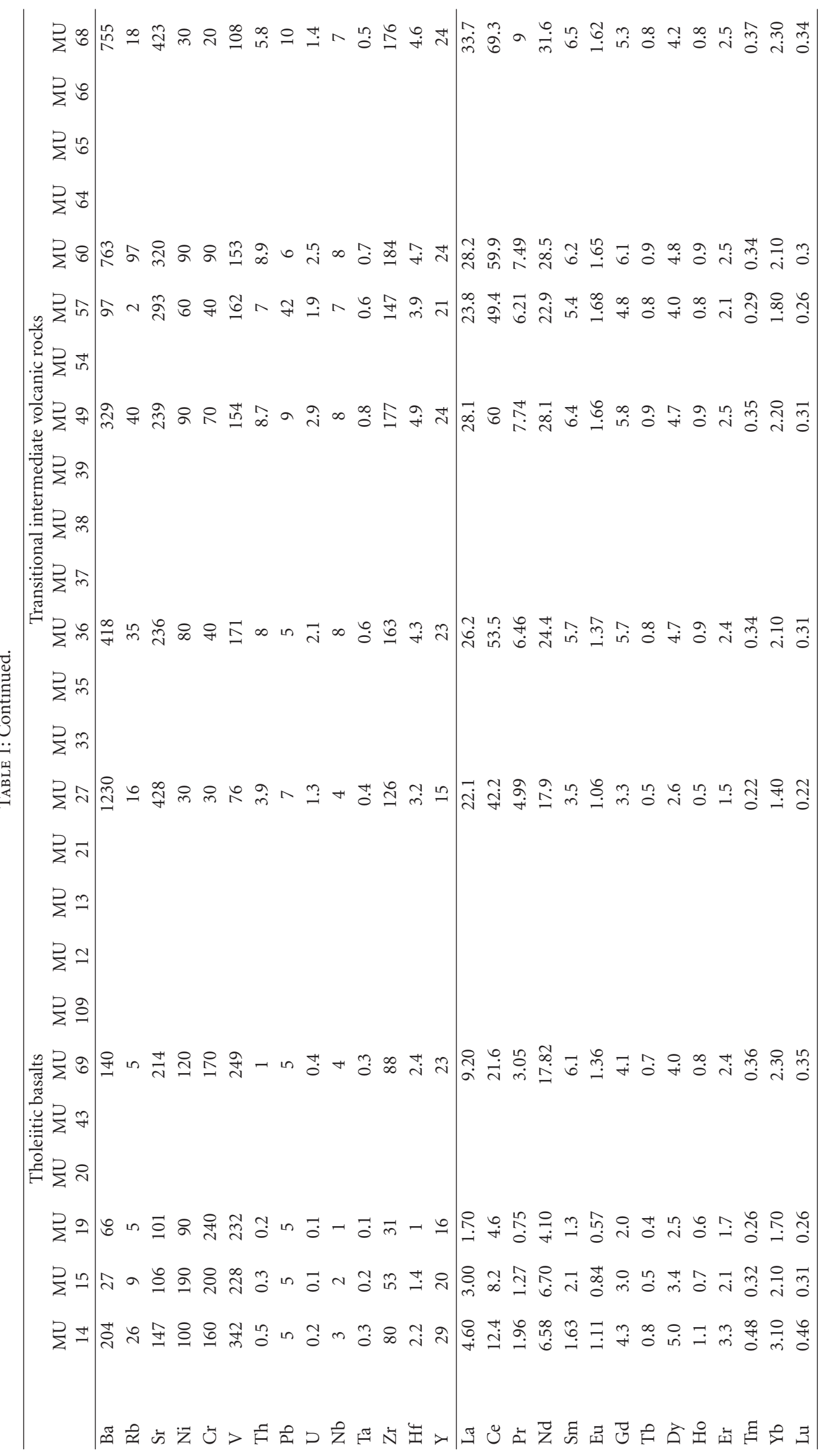




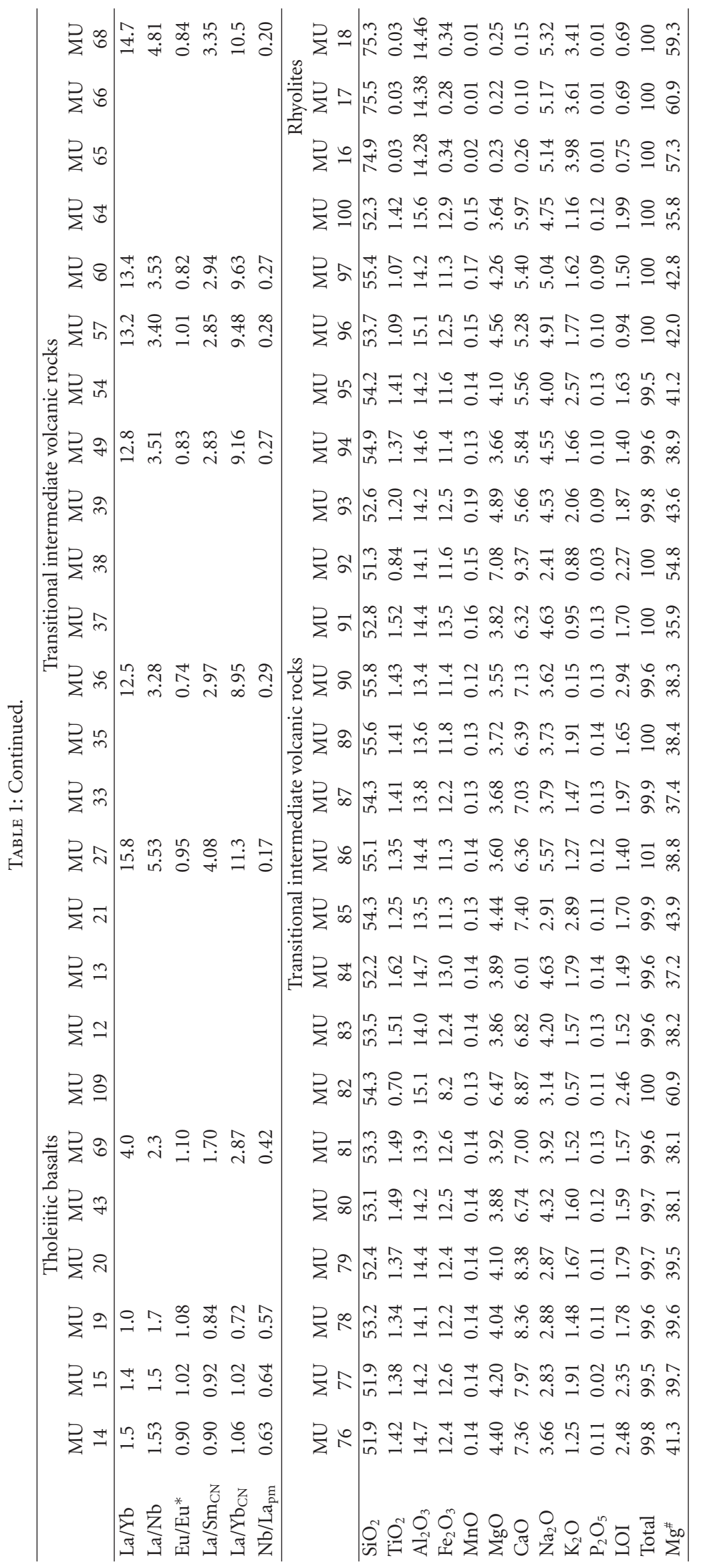




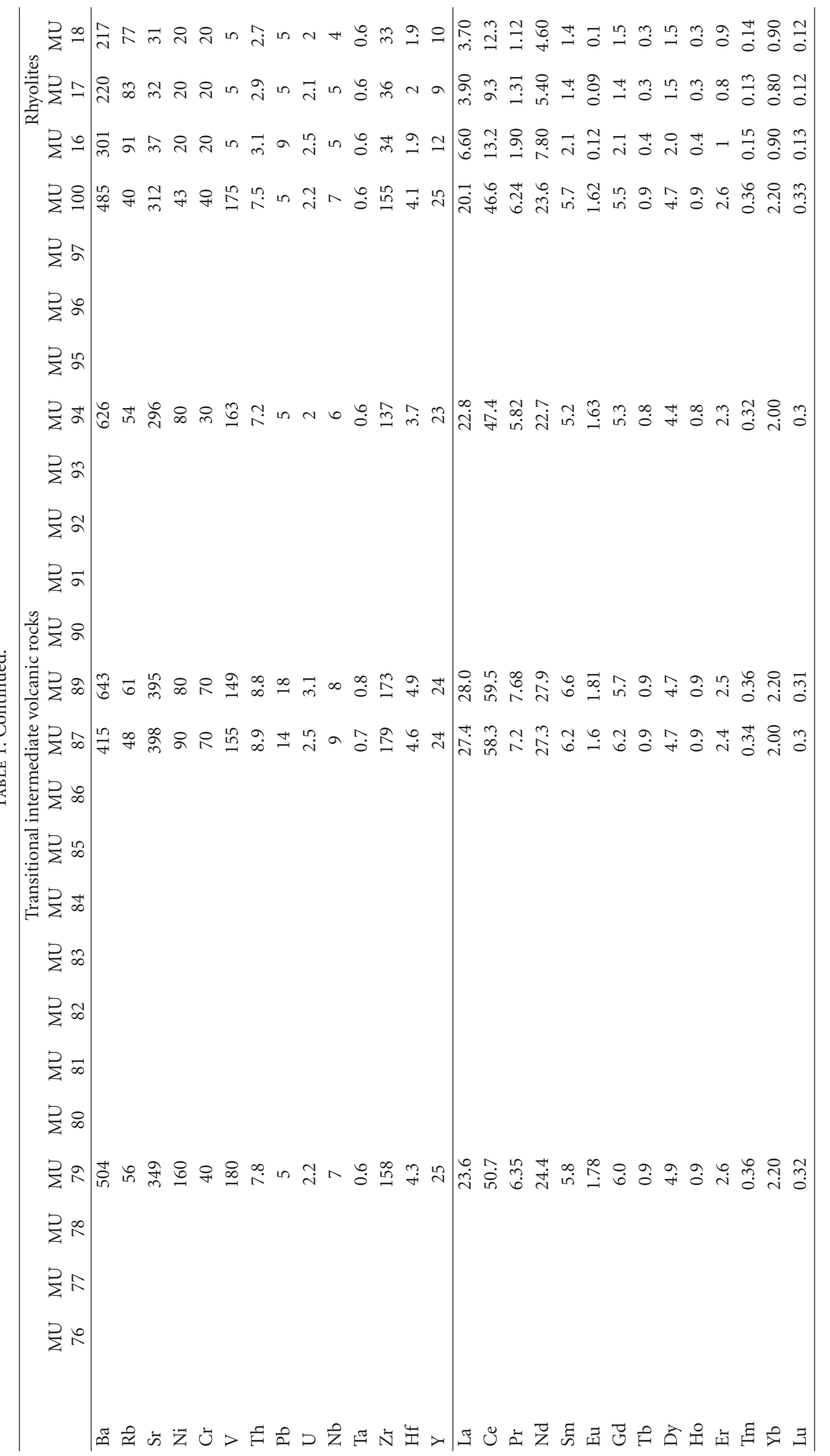




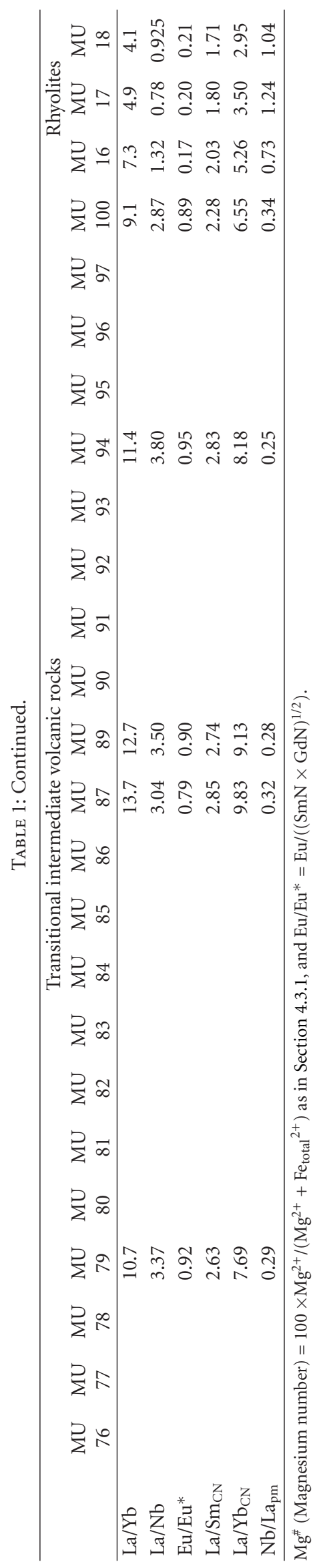




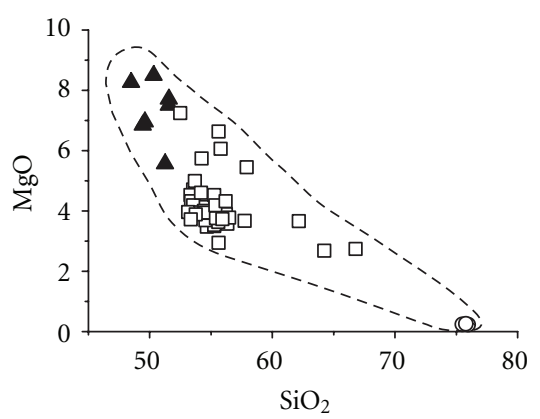

(a)

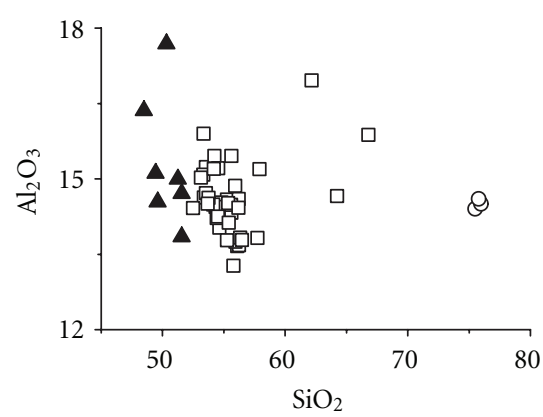

(d)

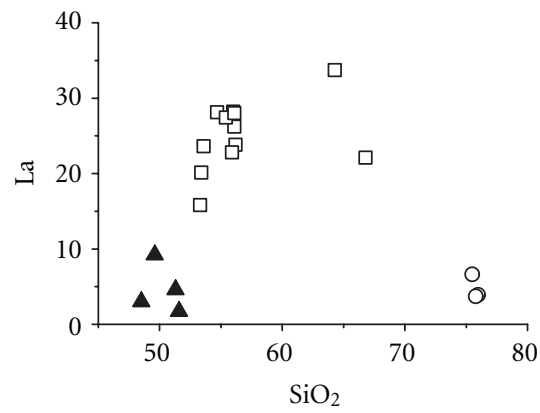

(g)

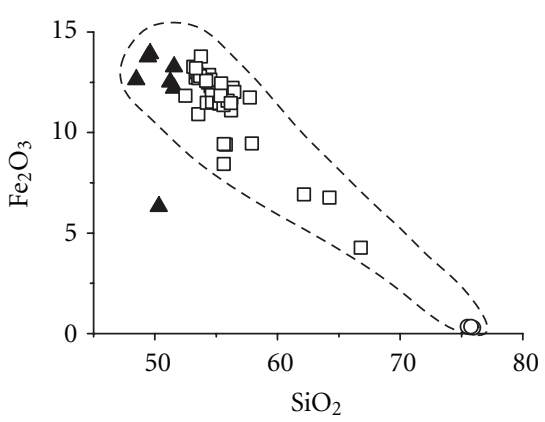

(b)

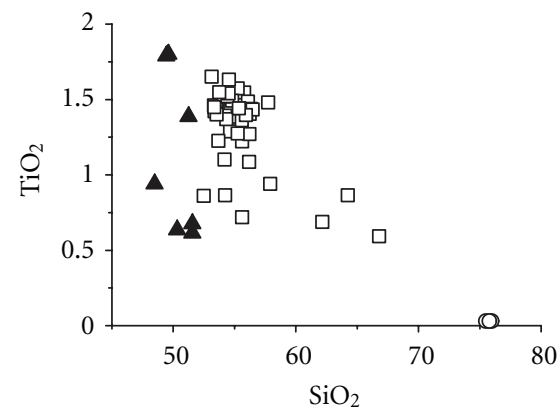

(e)

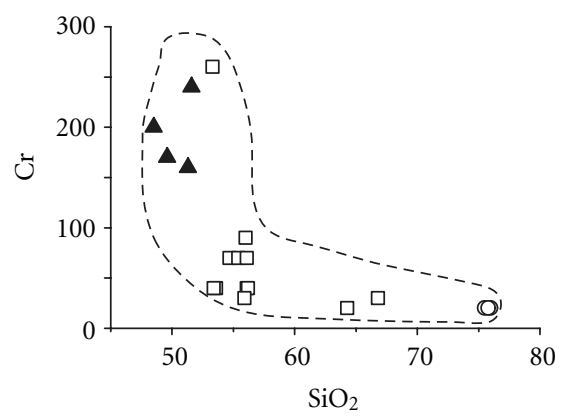

(h)

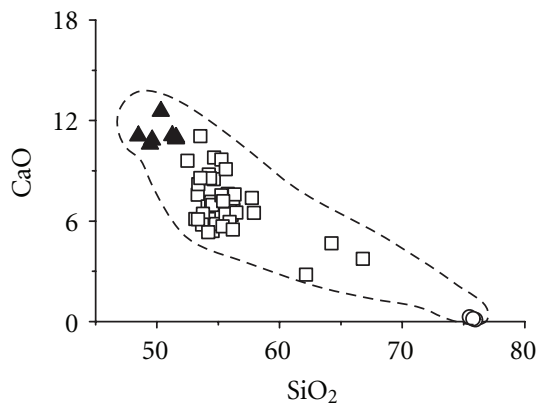

(c)

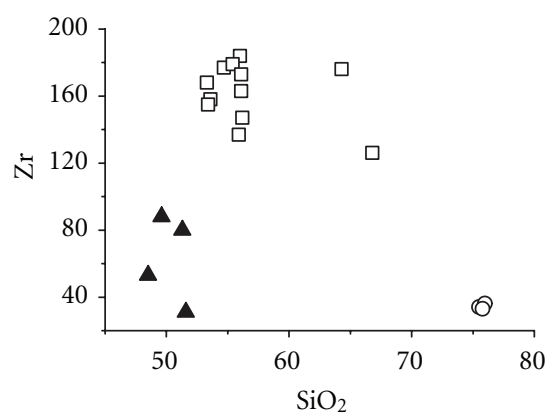

(f)

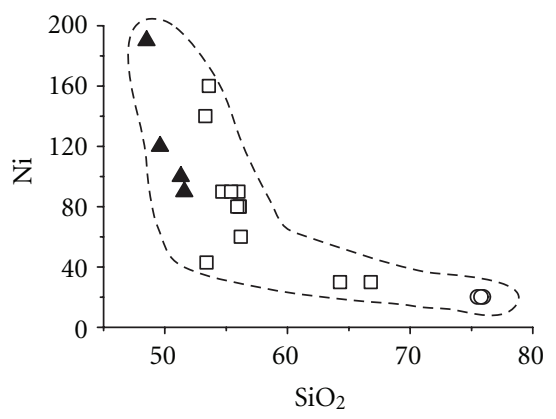

(i)

FIgURe 7: Major and trace elements variation diagram for the Kilimafedha volcanic rocks. Symbols as in Figure 6.

4.3.2. Intermediate Volcanic Rocks. The intermediate volcanic rocks have a wide range of $\mathrm{SiO}_{2}$ contents (52.51-66.80 wt\%) spanning from basaltic andesites through basaltic trachyandesites and andesites to dacites. The compositions, however, are skewed to the basaltic andesitic compositions as indicated by the averages $\left(\mathrm{SiO}_{2}=52.51-66.80 \mathrm{wt} \%\right.$, average $=$ $55.67 \mathrm{wt} \%, n=40$, Table 1, Figures 5 and 6 ), and only 5 samples have $\mathrm{SiO}_{2}>57 \mathrm{wt} \%$. $\mathrm{TiO}_{2}$ contents are $0.59-$ $1.65 \mathrm{wt} \%, \mathrm{Fe}_{2} \mathrm{O}_{3}=4.26-13.78 \mathrm{wt} \%, \mathrm{MgO}=2.68-7.25 \mathrm{wt} \%$, and $\mathrm{Mg}$ numbers range from 36 to 61 . $\mathrm{Cr}$ and $\mathrm{Ni}$ contents are $20-90 \mathrm{ppm}$ and $30-160 \mathrm{ppm}$, respectively. La varies from 20.1-33.7 ppm and $\mathrm{Yb}$ from 1.4-2.3 ppm which results in $\mathrm{La} / \mathrm{Yb}$ ratios of 9.14-15.8.

The intermediate volcanic rocks display fractionated REE patterns (Figure 8(b)) and in comparison with the tholeiitic basalts are characterized by an enrichment of the LREE relative to the MREE and HREE $\left(\mathrm{La} / \mathrm{Sm}_{\mathrm{CN}}=2.3-\right.$ 4.1, $\left.\mathrm{La} / \mathrm{Yb}_{\mathrm{CN}}=6.5-11.3\right)$. The degree of REE fractionation, however, is less than that of adakites which have $\mathrm{La} / \mathrm{Sm}_{\mathrm{CN}}=$ $5.8, \mathrm{La} / \mathrm{Yb}_{\mathrm{CN}}=43.5$ [25, Figure $8(\mathrm{~b})$ ]. The rocks show slightly negative to nonexistent $\mathrm{Eu}$ anomalies $\left(\mathrm{Eu} / \mathrm{Eu}^{*}=0.74-1.01\right)$. On the primitive mantle-normalized diagram (Figure 9(b)), the samples display fractionated patterns with enrichment of the incompatible elements $(\mathrm{Rb}, \mathrm{Ba}, \mathrm{Th}, \mathrm{K}$, and $\mathrm{Pb})$ relative to the compatibles ones and are associated with negative anomalies of $\mathrm{Nb}, \mathrm{Ta}$, and $\mathrm{Ti}$ relative to adjacent elements $\left(\mathrm{Nb} / \mathrm{La}_{\mathrm{pm}}=0.17-0.34\right)$.

4.3.3. Rhyolites. The rhyolite samples have a restricted range in $\mathrm{SiO}_{2}$ contents $(75.52-76.02 \mathrm{wt} \%, n=3) . \mathrm{TiO}_{2}$ contents are $0.03 \mathrm{wt} \%$ for all the 3 samples, whereas $\mathrm{Fe}_{2} \mathrm{O}_{3}$ and $\mathrm{MgO}$ vary from 0.28 to $0.34 \mathrm{wt} \%$ and from 0.22 to $0.25 \mathrm{wt} \%$, respectively. The samples are depleted in $\mathrm{Cr}$ and $\mathrm{Ni}(\leq 20 \mathrm{ppm})$ as well as in $\mathrm{Zr}(33-36 \mathrm{ppm})$. Compared with the tholeiitic basalts and the intermediate volcanic rocks, the rhyolites have lower total REE contents. La varies from 3.7 to 


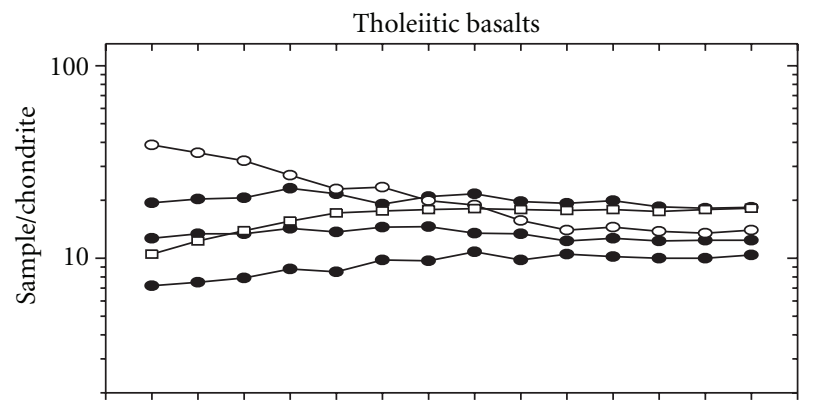

La Ce Pr Nd Sm Eu Gd Tb Dy Ho Er Tm Yb Lu

$\begin{array}{ll}\because \text { MU14 } & \longrightarrow \text { MU69 } \\ \because \text { MU15 } & \rightarrow \text { NMORB } \\ & \text { MU19 }\end{array}$

(a)

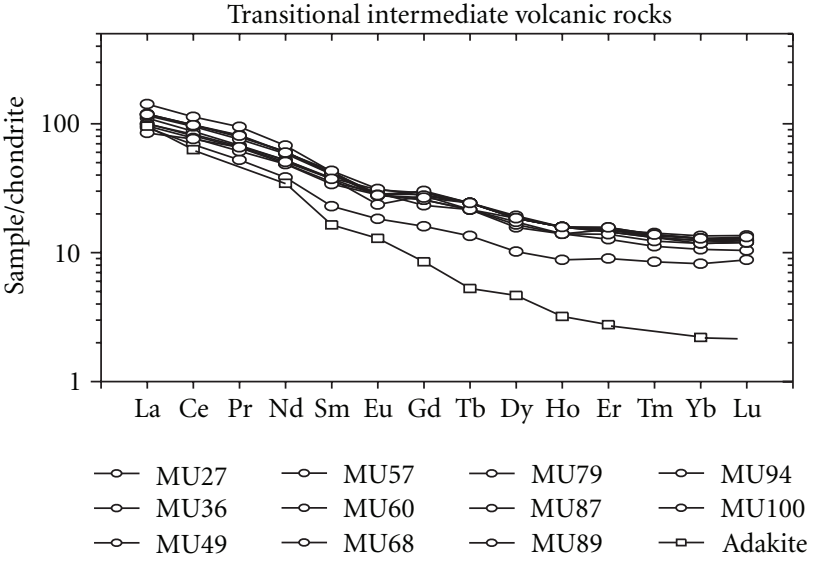

(b)

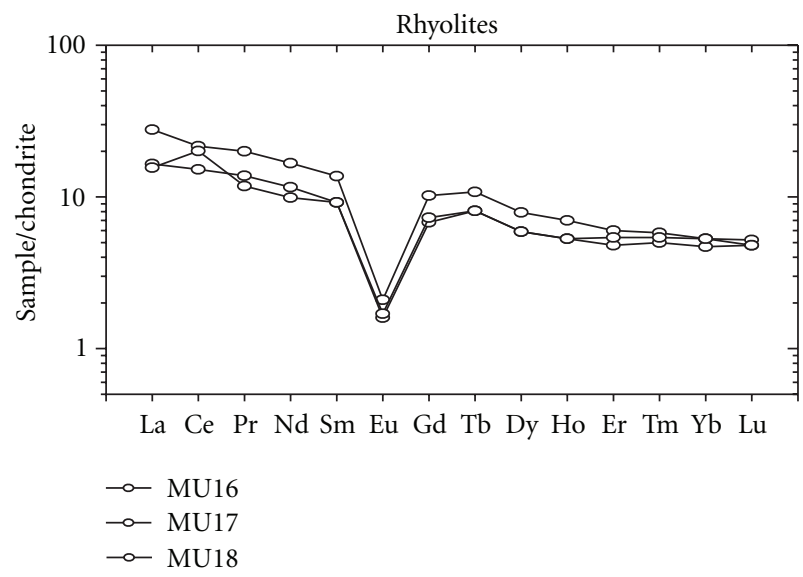

(c)

Figure 8: Chondrite normalized REE diagrams for the Kilimafedha volcanic rocks normalizing values from Sun and McDonough [23]. (a) Tholeiitic basalts superimposed with NMORB, (b) intermediate volcanic rocks superimposed with adakites, and (c) rhyolites.

$6.6 \mathrm{ppm}$, whereas $\mathrm{Yb}$ is restricted in the range of 0.8-0.9 ppm resulting into $\mathrm{La} / \mathrm{Yb}$ ratios of 4.11-7.13.

The rhyolites are characterized by slight enrichment of the LREE relative to MREE and $\operatorname{HREE}\left(\mathrm{La} / \mathrm{Sm}_{\mathrm{CN}}=1.7-2.0\right.$, $\left.\mathrm{La} / \mathrm{Yb}_{\mathrm{CN}}=2.95-5.26\right)$ with characteristic strong negative Eu anomalies $\left(\mathrm{Eu} / \mathrm{Eu}^{*}=0.17-0.21\right.$, Figure $\left.8(\mathrm{c})\right)$. On primitive mantle-normalized plots (Figure 9(c)), the samples show enrichment in incompatible elements $(\mathrm{Rb}, \mathrm{Ba}, \mathrm{Th}, \mathrm{K}$, and $\mathrm{Pb}$ ), negative anomalies of $\mathrm{Nb}, \mathrm{Ta}, \mathrm{Eu}, \mathrm{Sr}$, and $\mathrm{Ti}$ anomalies relative to adjacent elements.

4.4. Sm-Nd Isotopic Composition. Sm-Nd isotopic compositions for the Kilimafedha greenstone belt rhyolites are reported in Table 2. Also shown in the Table are the $\varepsilon \mathrm{Nd}$ values calculated assuming a crystallization age of $2712 \pm$ $5 \mathrm{Ma}$ reported by Wirth et al. [9]. The $\varepsilon \mathrm{Nd}(2.7 \mathrm{Ga})$ values range from +1.87 to +2.18 for the tholeiitic basalts, +1.57 to +2.46 for the intermediate volcanic rocks, and -0.51 to +5.16 for the rhyolites (Figure 10), and these values are comparable with those from the volcanic rocks from the northern Musoma-Mara greenstone belt reported by Manya et al. [11, 12], some few hundreds of km north of the Kilimafedha greenstone belt. Their respective depleted mantle $\left(\mathrm{T}_{\mathrm{DM}}\right)$ ages are 2980-3763 Ma, 2846-2970 Ma, and 2557-3914 Ma (Table 2).

\section{Discussion}

\subsection{Petrogenesis}

5.1.1. Tholeiitic Basalts. The slight depletion in LREE to nearly flat REE patterns shown by the tholeiitic basalts coupled with their close compositional similarity to $\mathrm{N}$ MORB suggests that these rocks were generated in a source similar to that generating modern N-MORB. Unlike NMORB, however, these patterns display negative anomalies in $\mathrm{Nb}$ and $\mathrm{Ti}$, features which together with tectonic setting discrimination diagrams (see next section) are suggestive of derivation in a subduction setting. The nature of the mantle source rocks can further be constrained by the trace element ratios $\mathrm{Nb} / \mathrm{Yb}, \mathrm{Zr} / \mathrm{Yb}$, and $\mathrm{Th} / \mathrm{Yb}$ [26]. When plotted on the $\mathrm{Nb} / \mathrm{Yb}$ versus $\mathrm{Zr} / \mathrm{Yb}$ diagram (Figure 11), the tholeiitic basalts plot around NMORB with a general trend towards increasing mantle enrichment to E-MORB within the MORB 

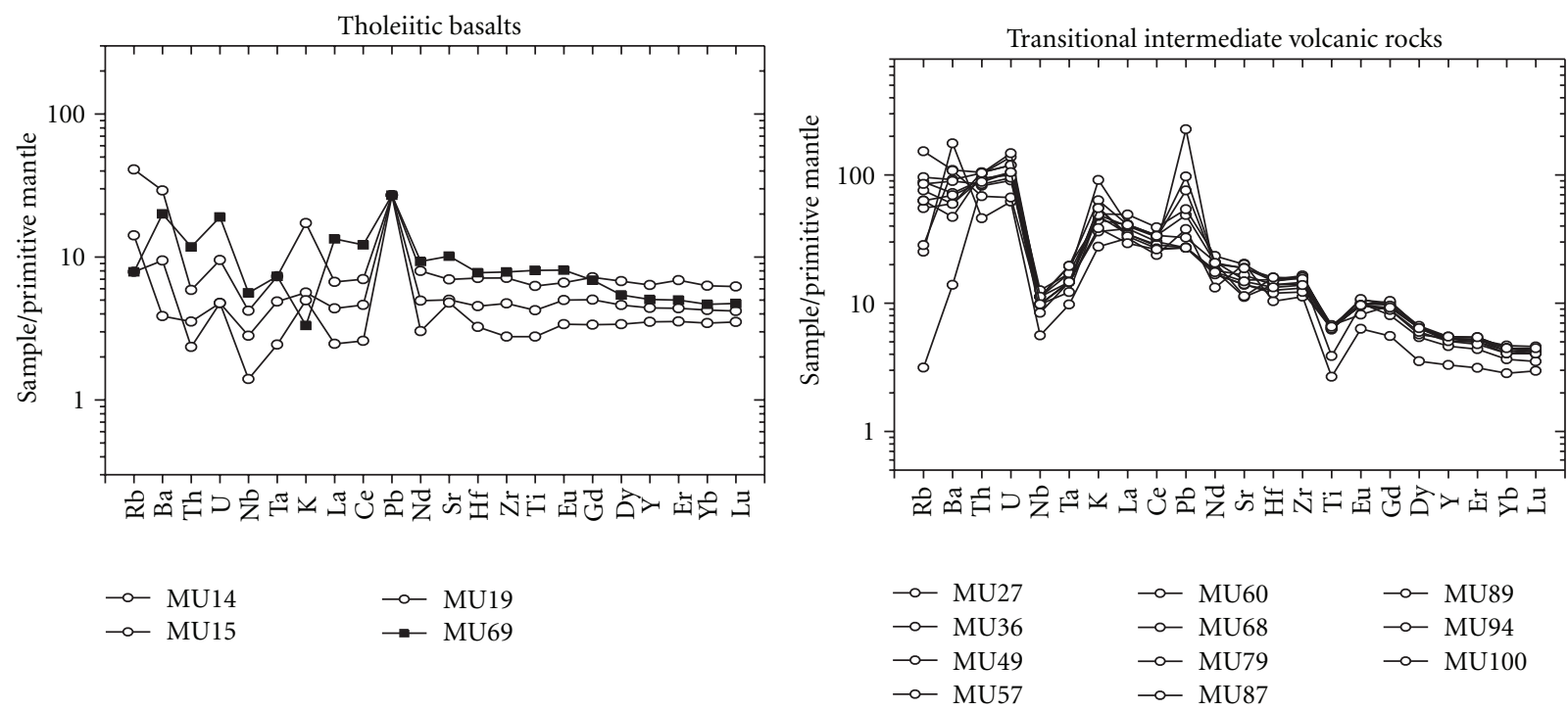

(a)

(b)

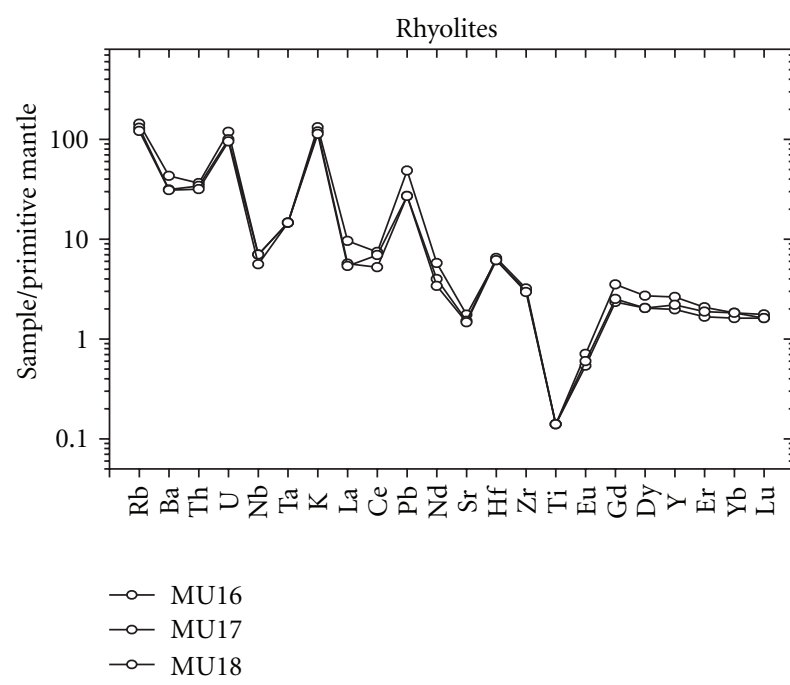

(c)

Figure 9: Primitive mantle normalized diagrams for the Kilimafedha volcanic, normalizing values from Sun and McDonough [23]. (a) Tholeiitic basalts, (b) intermediate volcanic rocks, and (c) rhyolites.

TABLE 2: Sm-Nd isotopic data for the Kilimafedha greenstone belt volcanic rocks.

\begin{tabular}{|c|c|c|c|c|c|c|c|}
\hline Sample & Rock suite & Sm (ppm) & $\mathrm{Nd}(\mathrm{ppm})$ & ${ }^{147} \mathrm{Sm} /{ }^{144} \mathrm{Nd}$ & ${ }^{143} \mathrm{Nd} /{ }^{144} \mathrm{Nd}$ & $\varepsilon \mathrm{Nd}($ at $2.7 \mathrm{Ga})$ & $\mathrm{T}_{\mathrm{DM}}(\mathrm{Ma})$ \\
\hline MU 14 & \multirow{2}{*}{ Tholeiite basalts } & 1.68 & 6.57 & 0.1545 & 0.511995 & 2.18 & 2980 \\
\hline MU 69 & & 6.12 & 18.82 & 0.1965 & 0.512731 & 1.87 & 3763 \\
\hline MU 49 & \multirow{5}{*}{ Transitional intermediate volcanic rocks } & 6.09 & 29.4 & 0.1252 & 0.511451 & 1.82 & 2923 \\
\hline MU 57 & & 5.06 & 24.2 & 0.1263 & 0.511481 & 1.99 & 2910 \\
\hline MU 68 & & 6.08 & 33.3 & 0.1103 & 0.511218 & 2.46 & 2846 \\
\hline MU 89 & & 6.02 & 28.7 & 0.1267 & 0.51148 & 1.83 & 2926 \\
\hline MU 100 & & 5.45 & 24.6 & 0.1339 & 0.511594 & 1.57 & 2970 \\
\hline MU 16 & \multirow{2}{*}{ Rhyolites } & 1.94 & 6.81 & 0.1721 & 0.512459 & 5.10 & 2557 \\
\hline MU 17 & & 1.37 & 4.51 & 0.1835 & 0.512378 & -0.51 & 3914 \\
\hline
\end{tabular}




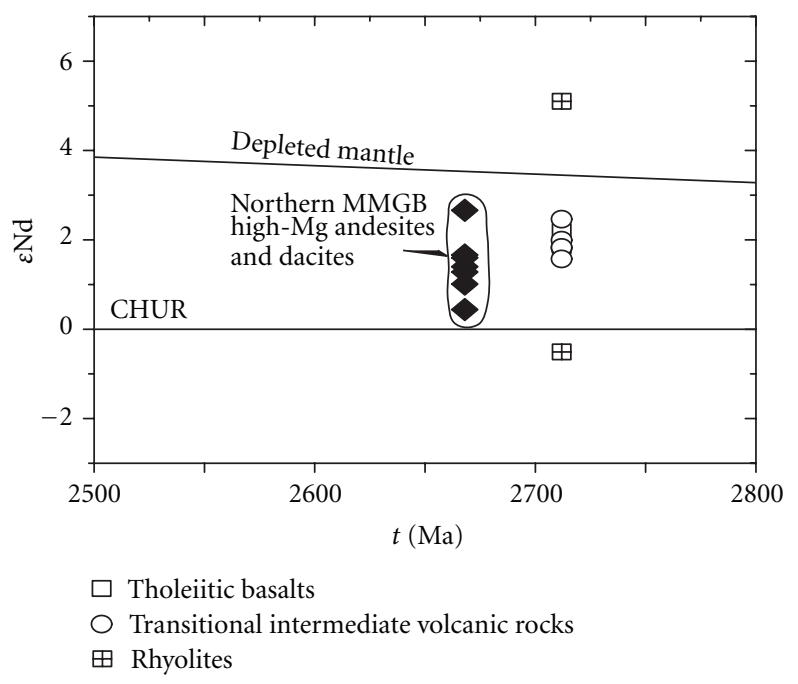

Figure 10: Plot of $\varepsilon N d$ versus $t(\mathrm{Ma})$ for the Kilimafedha greenstone belt volcanic rocks. The depleted mantle model is from DePaolo [24] and the northern Musoma-Mara greenstone belt high-Mg andesites and dacites data is from Manya et al. [11].

array. This suggests that the enrichment observed in the Kilimafedha tholeiites can be explained by their derivation from an initially homogeneous MORB-like source that was differentially metasomatized by an aqueous fluid derived from the subducting slab [26]. Fluxing of the source by the metasomatizing fluid most likely enhanced melting of the mantle wedge at a relatively low pressure. Melting of the mantle wedge which was not affected significantly by the metasomatism yielded the La-depleted basalts, whereas the La-enriched basalts were produced by melting of a mantle wedge that has been slightly metasomatized. The compositional similarity to NMORB is also reflected in similar $\varepsilon \mathrm{Nd}(2.7 \mathrm{Ga})$ of the samples $(+2.18$ for sample $\mathrm{MU}$ 14) to the depleted mantle value of 2.2 [24] at the same time. The slightly lower $\varepsilon \mathrm{Nd}(2.7 \mathrm{Ga})$ values of 1.87 for sample MU 69 would indicate minimal contamination of the magmas by older continental crust.

5.1.2. Intermediate Volcanic Rocks. Unlike the flat REE patterns that characterize the tholeiitic basalts, the intermediate rocks show fractionated patterns characterized by $\mathrm{La} / \mathrm{Yb}$ ratios of 9.14-15.8. These ratios are, however, lower than those reported in adakites $(\mathrm{La} / \mathrm{Yb}=40 ;[23])$. In adakites, such high ratios are indicative of the presence of garnet \pm amphibole in the source during partial melting. Thus, the lower $\mathrm{La} / \mathrm{Yb}$ ratios of the rocks preclude the involvement of garnet \pm amphibole in their magma genesis. In Figure 11, the intermediate volcanic rocks cluster just above E-MORB out of the MORB array towards increasing $\mathrm{Zr}$ content, which according to Pearce and Peate [26] signifies the involvement of both slab melt and hydrous fluid in metasomatising the source rocks. The metasomatism resulted in the enrichment of the source mantle wedge in the HFSE that has been scavenged from the subducting oceanic slab thereby explaining the observed enrichment in the HFSE relative to MORB (Figure 11). The involvement of slab partial melts in the petrogenesis of the intermediate volcanic rocks suggests that temperatures in the subduction zone were sufficiently high to initiate partial melting of the slab. According to Pearce and Peate [26], the onset of melting of the subducting slab in the Phanerozoic occurs at relatively greater depth $(>100 \mathrm{~km}$ ) beneath the subduction zone. This suggests that, unlike the tholeiitic basalts that were formed at relatively shallow depths, the primary magmas for the intermediate volcanic rocks originated at greater depth, but outside the garnet stability field. The intermediate volcanic rocks have $\varepsilon \mathrm{Nd}(2.7 \mathrm{Ga})$ values of +1.57 to +2.46 similar to those of the tholeiitic basalts and are indicative of the juvenile nature of the magmas accompanied by minimal crustal contamination. Such a conclusion was also reached for the northern MMGB high-Mg andesites and dacites [11] which share similar $\varepsilon N d$ values with the Kilimafedha greenstobe belt volcanic rocks.

5.1.3. Rhyolites. Rhyolites differ from the other two suites in having lower contents of $\mathrm{TiO}_{2}, \mathrm{P}_{2} \mathrm{O}_{5}, \mathrm{Zr}$, and overall lower abundances of the REE (Table 1). In chondrite normalized REE diagrams (Figure 8) and extended trace element diagram (Figure 9), the rhyolites are characterized by large negative $\mathrm{Eu}\left(\mathrm{Eu} / \mathrm{Eu}^{*}=0.17-0.21\right.$, Table 1$)$ accompanied by negative $\mathrm{Sr}$ anomalies as well as $\mathrm{Nb}$ and $\mathrm{Ti}$ anomalies. The close spatial association of the rhyolites and other suites of the Kilimafedha greenstone belt coupled with their trends towards lower $\mathrm{Fe}_{2} \mathrm{O}_{3}, \mathrm{MgO}, \mathrm{CaO}, \mathrm{TiO}_{2}, \mathrm{Cr}$, and $\mathrm{Ni}$ with increasing $\mathrm{SiO}_{2}$ (Figure 7) may suggest that the rhyolites may be products of extensive fractional crystallization of the same magmas that generated the more basic members. Such a model is also supported by experimental studies which showed that low-pressure fractional crystallization of olivine, pyroxene, plagioclase, and Fe-Ti oxides can produce rhyolites [27] with relatively flat HREE patterns. Thus, the generally lower REE abundances, $\mathrm{TiO}_{2}, \mathrm{P}_{2} \mathrm{O}_{5}$, and $\mathrm{Zr}$ contents can be explained by shallow level fractionation of Ti-rich phases (e.g., titanomagnetite) and REE-rich phases such as apatite, 


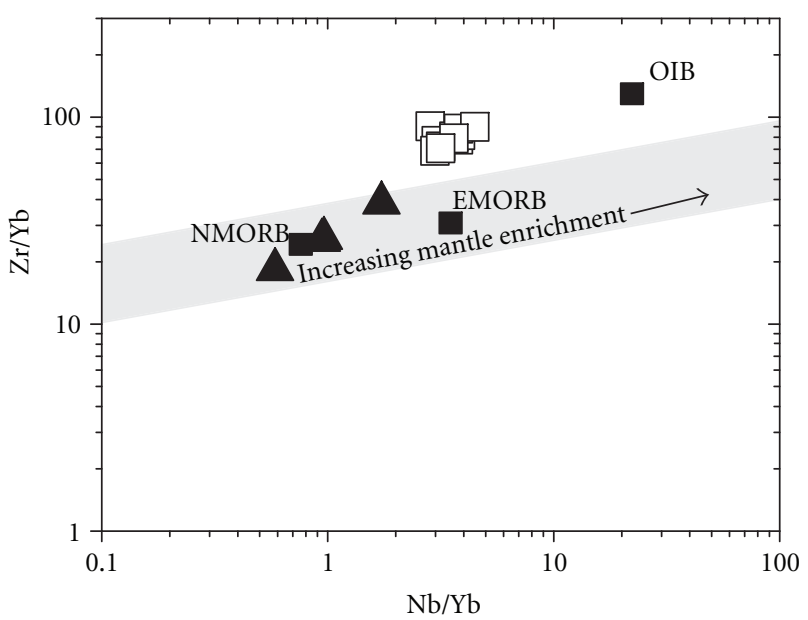

Figure 11: Nb/Yb-Zr/Yb diagram (after Pearce and Peate, [26]) for the Kilimafedha tholeiitic basalts (filled triangles) and intermediate volcanic rocks (open squares). The tholeiitic basalt samples plot around the NMORB field tending towards the mantle enrichment direction within the MORB array suggestive of metasomatism by aqueous fluid. The intermediate rocks plot just above the EMORB tending to higher $\mathrm{Zr}$ values illustrating input of the HFSE from the subducted slab. NMORB, EMORB, and OIB data are from Sun and McDonough [23].

monazite, zircon, and allanites, whereas the large negative Eu and $\mathrm{Sr}$ anomalies could be due to plagioclase fractionation. Compared to the other two suites, the rhyolites show variable $\varepsilon \mathrm{Nd}(2.7 \mathrm{Ga})$ values of -0.51 to +5.17 and suggest that older crustal involvement in the genesis of the rhyolites either by partial melting of older crust or contamination of evolving magmatic liquid cannot be ruled out as an important process in the genesis of these rocks. The wide variation in $\varepsilon \mathrm{Nd}$ towards more depleted signatures demands reexamination of the rocks.

5.2. Tectonic Setting. Trace element discrimination diagrams developed for Phanerozoic rocks have been used together with their ratios to infer the tectonic setting for Archaean rocks (e.g., [19]). Using this approach, the Kilimafedha tholeiitic basalts and basaltic andesites were plotted on the Th-Hf-Nb triangular diagram of Wood [28] which is suitable for mafic as well as intermediate volcanic rocks. On this diagram, three of the four tholeiitic basalt samples plot along the boundary between the N-MORB and EMORB fields, while the other samples together with all intermediate volcanic samples plot in the field of volcanic arc basalts (Figure 12). The similarity of the three tholeiitic basalt samples with $\mathrm{N}-\mathrm{MORB}$ on the Th-Hf-Nb diagram is also reflected in Figure $8(\mathrm{a})$. The $\mathrm{La} / \mathrm{Nb}$ ratio of basaltic samples is particularly important in discriminating basalts that erupted in ocean ridges and ocean plateaus from those that erupted in arcs [29, 30]. According to Rudnick [29] and Condie [30], ocean ridge and ocean plateau basalts have $\mathrm{La} / \mathrm{Nb}<1.4$, whereas arc basalts have $\mathrm{La} / \mathrm{Nb}>1.4$. Both the tholeiitic basalts and intermediate rocks of the Kilimafedha greenstone belt show $\mathrm{La} / \mathrm{Nb}>1.4(1.5-2.30$ and 2.87-5.53, resp.) suggestive of arc affinities. Thus, the results obtained from the discrimination diagrams combined with trace element ratios data are suggestive of an arc tectonic setting for the Kilimafedha greenstone belts rocks.
This conclusion is supported by the fact that the rocks exhibit negative anomalies of $\mathrm{Nb}, \mathrm{Ti}$, and/or $\mathrm{Ta}$ anomalies in extended trace element spidergrams (Figure 9), features attributed to magmas generated at subduction zones [26].

\section{Comparison with Other Greenstone Belts of the Tanzania Craton}

A closer review of geochemistry and geochronology by Manya et al. [10] and Manya and Maboko [8] showed that the individual greenstone belts of the Tanzania Craton exhibit different formation ages, and their formation occurred in different tectonic settings. This suggestion is also evident in different volcanic rock packages found in these belts. Kilimafedha greenstone belt (KGB) differs from the Sukumaland (SGB) to the west and Iramba-Sekenke (ISGB) to the far south in having predominantly intermediate volcanic rocks with tholeiitic to calc-alkaline intermediate affinities, rare mafic, and felsic volcanic package, which are in contrast to the later that are dominated by tholeiitic basalts and rare intermediate volcanic rocks. The volcanic package in KGB also differs from those of the southern MusomaMara greenstone belt (MMGB) to the near north as the later is comprised of bimodal volcanic assemblage [31]. Although the northern part of the MMGB is predominantly comprised of intermediate rocks similar to KGB, the former lacks mafic members.

The foregoing discussion corroborates the findings by Manya et al. [10] that the individual greenstone belts evolved as separate entities at different time intervals having different volcanic rocks assemblages. Although volcanism in greenstone belts of the Tanzania Craton seems to have erupted at different time intervals (2823-2780 Ma for SGB, 2755-2712 Ma for MMGB, ISGB, and KGB, 2676-2667 Ma for northern MMGB, [8] and references therein); one thing is common to all of them: they formed exclusively 


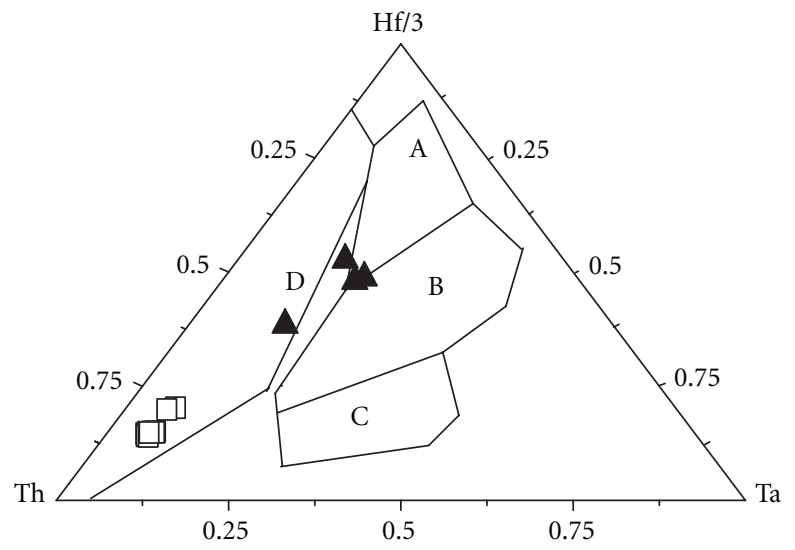
(A) N-type MORB
(B) E-type MORB and within-plate tholeiites
(C) Alkaline within-plate basalts
(D) Volcanic arc basalts

FIgURE 12: Ta-Hf-Th tectonic setting discrimination diagram [28] for the tholeiitic basalts (filled triangles) and intermediate volcanic rocks (open squares) for the Kilimafedha greenstone belts.

at convergent margins. This signifies the importance of formation and growth of late Archaean continental crust at convergent margins.

\section{Conclusion}

The Neoarchaean Kilimafedha greenstone belt of northeastern Tanzania consists of three closely associated suites of volcanic rocks: the predominant intermediate basaltic andesite and dacites, and the volumetrically minor tholeiitic basalts and rhyolites. The tholeiitic basalts have nearly flat REE patterns and show close compositional similarity to NMORB. Trace element systematics of the tholeiites suggest that they were formed by shallow partial melting of a mantle wedge that has been variably metasomatized by an aqueous fluid in a convergent tectonic setting. The intermediate rocks are characterized by fractionated REE patterns, enrichment of the HFSE relative to NMORB, and negative anomalies of $\mathrm{Nb}$ and $\mathrm{Ta}$. Such geochemical features are consistent with derivation of these rocks by partial melting of a mantle wedge that has been metasomatized by both fluid and slab melt at a greater depth than the tholeiitic basalts source but outside the garnet stability field. The geochemical features defining the Kilimafedha greenstone belt rhyolites include low $\mathrm{TiO}_{2}, \mathrm{P}_{2} \mathrm{O}_{5}, \mathrm{Zr}$, and overall lower abundance of total REE compared with the other two suites and large negative $\mathrm{Eu}, \mathrm{Sr}$, and $\mathrm{Ti}$ anomalies in extended trace element spidergrams. These features can be explained by shallow level fractional crystallization of the parent magma of the intermediate volcanic rocks involving plagioclase, Ti-rich phases like ilmenite and magnetite as well as REE-rich phases like apatite, zircon, monazite, and allanite. The close spatial association of the three petrological types in the Kilimafedha greenstone belt is interpreted as reflecting their formation in an evolving late Achaean island arc.

\section{Acknowledgments}

This research was financially supported by Sida/SAREC through the project Research Capacity Building at the Faculty of Science, now College of Natural and Applied Sciences (CoNAS), University of Dar es Salaam, to which the authors are greatly indebted. The authors are also thankful to Michael O. Garcia, the Journal Editor and two anonymous reviewers for their insightful comments that helped shape the paper.

\section{References}

[1] G. Borg and R. M. Shackleton, "The Tanzania and NE Zaire cratons," in Greenstone Belts, M. J. de Wit and L. D. Ashwal, Eds., pp. 608-619, Clarendon Press, Oxford, UK, 1997.

[2] G. Borg, "The Geita gold deposit in NW Tanzania-geology, ore petrology, geochemistry and timing of events," Geologisches Jahrbuch D, vol. 100, pp. 545-595, 1994.

[3] E. Kazimoto, Study of integrated geochemical techniques in the exploration for gold in North Mara mines, Tanzania [M.S. thesis], University of Dar es Salaam, 2008.

[4] G. Borg, "New aspects of the lithostratigraphy and evolution of the Siga Hills, an Archaean granite-greenstone terrain in NW Tanzania," Zeitschrift fur Angewandte Geologie, vol. 38, no. 2, pp. 89-93, 1992.

[5] S. Manya and M. A. H. Maboko, "Geochemistry of the Neoarchaean mafic volcanic rocks of the Geita area, NW Tanzania: implications for stratigraphical relationships in the Sukumaland greenstone belt," Journal of African Earth Sciences, vol. 52, no. 4-5, pp. 152-160, 2008.

[6] G. Borg and T. Krogh, "Isotopic age data of single zircons from the Archaean Sukumaland Greenstone Belt, Tanzania," Journal of African Earth Sciences, vol. 29, no. 2, pp. 301-312, 1999.

[7] S. Manya and M. A. H. Maboko, "Dating basaltic volcanism in the Neoarchaean Sukumaland Greenstone Belt of the Tanzania Craton using the Sm-Nd method: implications for 
the geological evolution of the Tanzania Craton," Precambrian Research, vol. 121, no. 1-2, pp. 35-45, 2003.

[8] S. Manya and M. A. H. Maboko, "Geochemistry and geochronology of Neoarchaean volcanic rocks of the IrambaSekenke greenstone belt, central Tanzania," Precambrian Research, vol. 163, no. 3-4, pp. 265-278, 2008.

[9] K. R. Wirth, J. D. Vervoot, and B. Weisberger, "Origin and evolution of the Kilimafedha greenstone belt, eastern Tanzania Craton: evidence from $\mathrm{Pb}$ isotopes," Geological Society of America Abstracts with Programs, vol. 36, p. 244, 2004.

[10] S. Manya, K. Kobayashi, M. A. H. Maboko, and E. Nakamura, "Ion microprobe zircon U-Pb dating of the late Archaean metavolcanics and associated granites of the Musoma-Mara Greenstone Belt, Northeast Tanzania: implications for the geological evolution of the Tanzania Craton," Journal of African Earth Sciences, vol. 45, no. 3, pp. 355-366, 2006.

[11] S. Manya, M. A. H. Maboko, and E. Nakamura, "The geochemistry of high-Mg andesite and associated adakitic rocks in the Musoma-Mara Greenstone Belt, northern Tanzania: possible evidence for Neoarchaean ridge subduction?" Precambrian Research, vol. 159, no. 3-4, pp. 241-259, 2007.

[12] S. Manya, M. A. H. Maboko, and E. Nakamura, "Geochemistry and $\mathrm{Nd}$-isotopic composition of potassic magmatism in the Neoarchaean Musoma-Mara Greenstone Belt, northern Tanzania," Precambrian Research, vol. 159, no. 3-4, pp. 231240, 2007.

[13] P. Pinna, S. Muhongo, B. A. Mcharo et al., "Geology and Mineral Map of Tanzania. Scale: 1:2.000.000,” BRGM-UDSMGST team, 2008.

[14] M. Macfarlane, "Brief explanation of the geology of quarter degree sheet 25, East Mara," Mineral Resource Division, Dodoma, Tanzania, 1965.

[15] T. N. Clifford, "The structural framework of Africa," in African Magmatism and Tectonics, Oliver and Boyd, T. N. Clifford and I. G. Gass, Eds., pp. 1-26, Edinburgh, UK, 1970.

[16] I. M. Gray and A. S. Macdonald, "Brief explanation of the geology of quarter degree sheet 6 and 14, Seronera," Mineral Resource Division, Dodoma, Tanzania, 1965.

[17] C. Kasanzu, M. A. H. Maboko, and S. Manya, "Geochemistry of fine-grained clastic sedimentary rocks of the Neoproterozoic Ikorongo Group, NE Tanzania: implications for provenance and source rock weathering," Precambrian Research, vol. 164, no. 3-4, pp. 201-213, 2008.

[18] C. W. A. Messo, Geochemistry of Neoarchaean volcanic rocks of the Ikoma area in the Kilimafedha greenstone belt, Northwestern Tanzania [M.S. thesis], University of Dar es Salaam, 2004.

[19] H. R. Rollinson, Using Geochemical Data: Evaluation, Presentation, Interpretation, Longman, Essex, UK, 1993.

[20] K. P. Jochum and S. P. Verma, "Extreme enrichment of Sb, Tl and other trace elements in altered MORB," Chemical Geology, vol. 130, no. 3-4, pp. 289-299, 1996.

[21] R. W. Le Maitre, P. Bateman, A. Dudek et al., A Classification of Igneous Rocks and Glossary of Terms, Blackwell, Oxford, UK, 1989.

[22] J. A. Winchester and P. A. Floyd, "Geochemical discrimination of different magma series and their differentiation products using immobile elements," Chemical Geology, vol. 20, no. C, pp. 325-343, 1977.

[23] S. S. Sun and W. F. McDonough, "Chemical and isotopic systematics of oceanic basalts: implications for mantle composition and processes," Magmatism in the ocean basins, pp. 313-345, 1989.
[24] D. J. DePaolo, "Neodymium isotopes in the Colorado Front Range and crust-mantle evolution in the Proterozoic," Nature, vol. 291, no. 5812, pp. 193-196, 1981.

[25] H. Martin, "Adakitic magmas: modern analogues of Archaean granitoids," Lithos, vol. 46, no. 3, pp. 411-429, 1999.

[26] J. A. Pearce and D. W. Peate, "Tectonic implications of the composition of volcanic arc magmas," Annual Review of Earth \& Planetary Sciences, vol. 23, pp. 251-285, 1995.

[27] S. D. Spulber and M. J. Rutherford, "The origin of rhyolite and plagiogranite in oceanic crust: an experimental study.," Journal of Petrology, vol. 24, no. 1, pp. 1-25, 1983.

[28] D. A. Wood, "The application of a Th-Hf-Ta diagram to problems of tectonomagmatic classification and to establishing the nature of crustal contamination of basaltic lavas of the British Tertiary Volcanic Province," Earth and Planetary Science Letters, vol. 50, no. 1, pp. 11-30, 1980.

[29] R. L. Rudnick, "Making continental crust," Nature, vol. 378, no. 6557, pp. 571-578, 1995.

[30] K. C. Condie, "Mafic crustal xenoliths and the origin of the lower continental crust," Lithos, vol. 46, no. 1, pp. 95-101, 1999.

[31] M. Mtoro, M. A. H. Maboko, and S. Manya, "Geochemistry and geochronology of the bimodal volcanic rocks of the Suguti area in the southern part of the Musoma-Mara Greenstone Belt, Northern Tanzania," Precambrian Research, vol. 174, no. 3-4, pp. 241-257, 2009. 

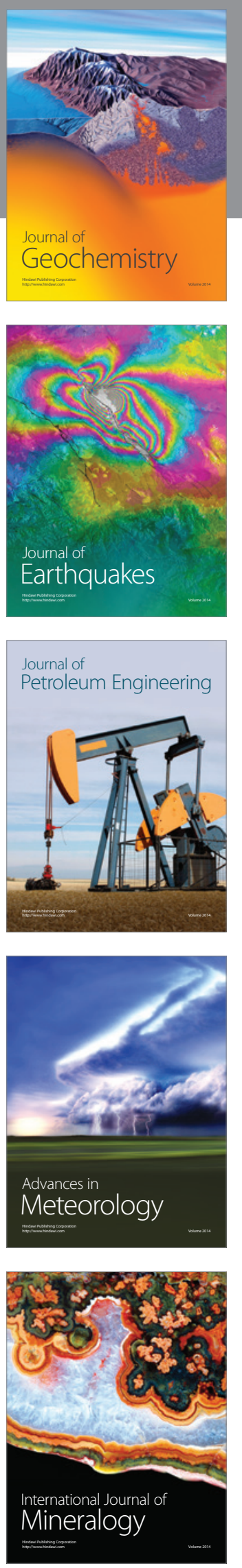
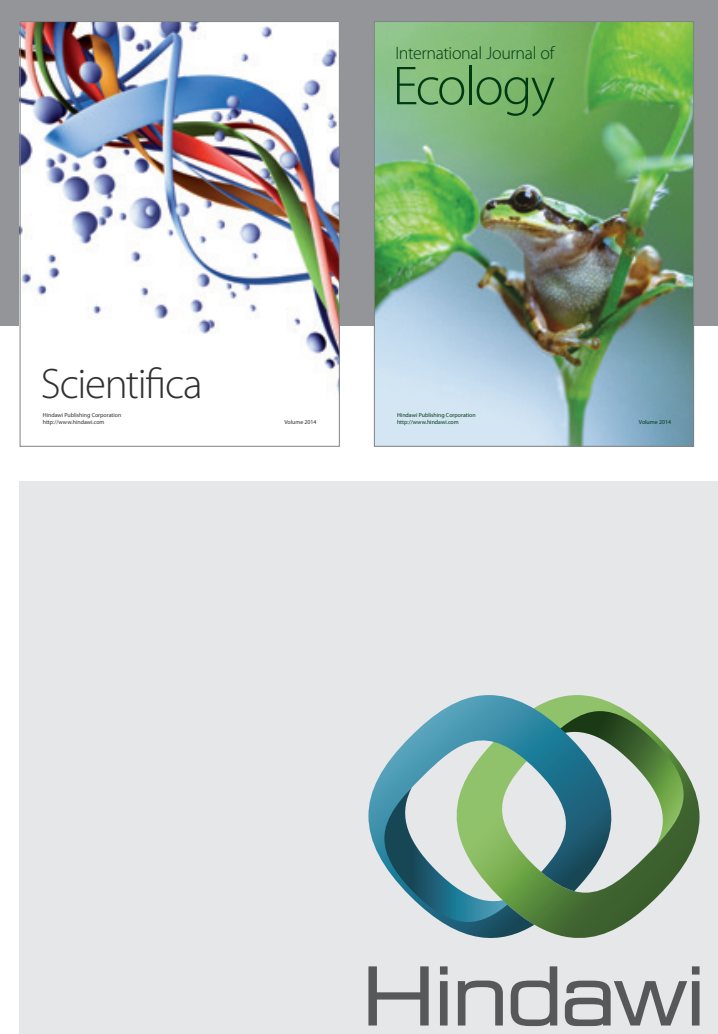

Submit your manuscripts at http://www.hindawi.com
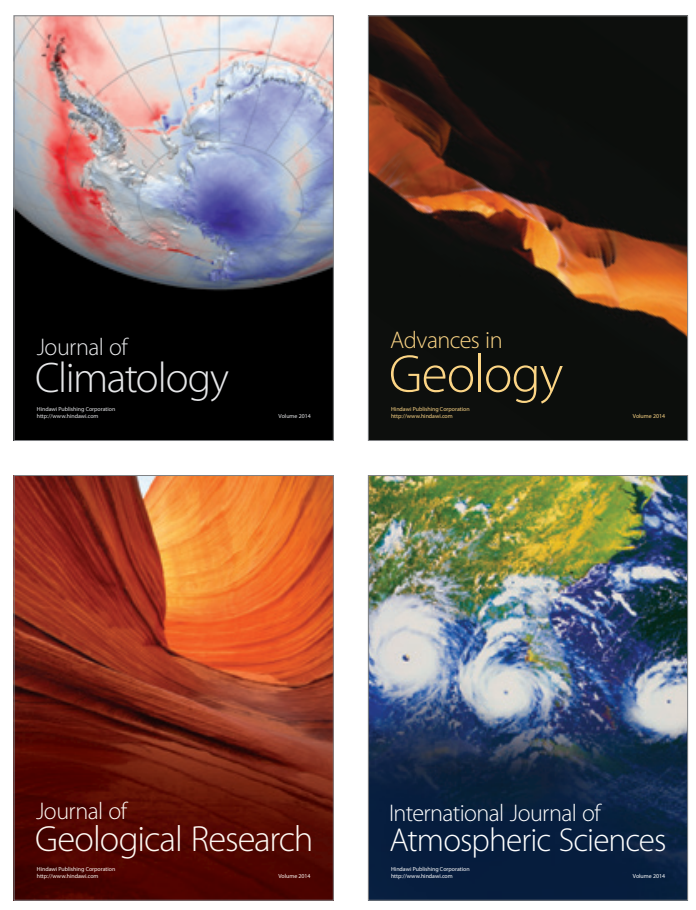
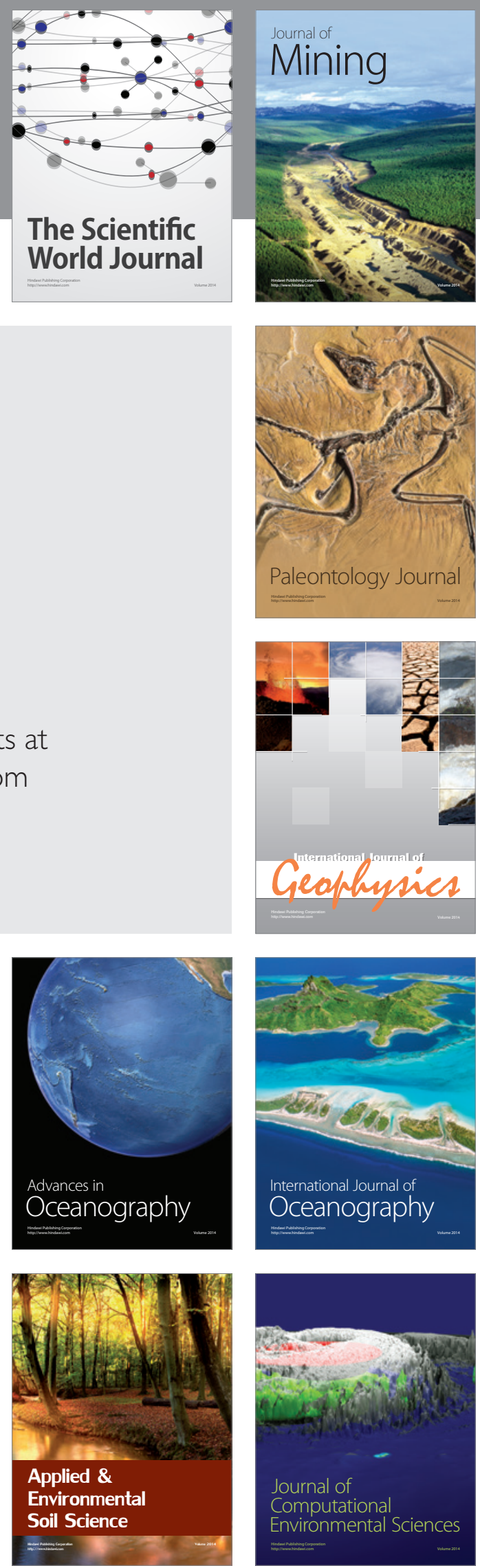